\title{
COMMENTS
}

\section{A Construction of Section 1985(c) in Light of Its Original Purpose $\dagger$}

The passage of the $\mathrm{Ku}$ Klux Klan Act of $1871^{1}$ was occasioned by tales of murders, whippings, and beatings committed by rogues in white sheets in the postbellum South. Many courts, however, have read the Act's broad language as providing remedies for wrongs far afield from Klan violence. Specifically, courts have found a cause of action under 42 U.S.C. $\$ 1985(\mathrm{c}),{ }^{2}$ the current codification of part of section 2 of the Act, in cases involving racial and genderbased discrimination in employment and interferences with contractual, property, and other rights apparently quite different from the types of abuse that motivated the drafters of the Act. ${ }^{3}$ The language of section 1985(c) that gives rise to this broad range of

$\dagger$ After this issue went to press, the Supreme Court decided Great Am. Fed. Sav. \& Loan Ass'n v. Novotny, 47 U.S.L.W. 4681 (U.S. June 12, 1979), rev'g 584 F.2d 1235 (3d Cir. 1978) (en banc), holding that a plaintiff may not base an action under section 1985(c) on a violation of Title VII. References to the Court's decision have been inserted in the footnotes where relevant.

1 Act of April 20,1871, ch. 22, $\S 2,17$ Stat. 13 (1871) (codified in part at 42 U.S.C. $\S \S$ 1983, 1985, 1986 (1976)). The Act is sometimes referred to as the Civil Rights Act of 1871 or the Force Act of 1871. The official title was "An Act to enforce the provisions of the Fourteenth Amendment to the Constitution of the United States, and for other purposes."

2 Until recently, the section under consideration was codified at 42 U.S.C. $\$ 1985(3)$ (1970). This comment refers to the statute as section 1985(c), regardless of its codification at the time of the cases discussed.

${ }^{3}$ E.g., Novotny v. Great Am. Fed. Sav. \& Loan Ass'n, 584 F.2d 1235 (3d Cir. 1978) (en banc), reo'd, 47 U.S.L.W. 4681 (U.S. June 12, 1979) (cause of action for gender-based discrimination based on Title VII); Bethel v. Jendoco Constr. Corp., 570 F.2d 1168 (3d Cir. 1978) (right to be free from racial discrimination by private employers); Kyriazi v. Western Elec. Co., 461 F. Supp. 894 (D.N.J. 1978); Marchwinski v. Oliver Tyrone Corp., 461 F. Supp. 160 (W.D. Pa. 1978) (right to freedom from gender-based discrimination by private employers); Fannie v. Chamberlain Mfg. Corp., 445 F. Supp. 65 (W.D. Pa: 1977) (action for gender-based discrimination by private employer apparently not based on Title VII right); Local No. 1 (ACA), Broadcast Employees v. International Bhd. of Teamsters, 419 F. Supp. 263 (E.D. $\mathrm{Pa}$. 1976) (cause of action for violation by union officials of union members' right to express views contrary to views of the union leadership); Beamon v. W.B. Saunders Co., 413 F. Supp. 1167 (E.D. Pa. 1976) (gender-based discrimination in employment; cause of action apparently not based on Title VII rights); Reichardt v. Payne, 396 F. Supp. 1010 (E.D. Cal. 1975) (cause of action against insurance companies that allegedly conspired to issue disability insurance policies discriminating against women); Pendrell v. Chatham College, 370 F. Supp. 494 (W.D. Pa. 1974) (cause of action against private employer for discharge of female employee because of her advocacy of the rights of blacks and women); Ackley v. Maple Woodman Assocs., 47 U.S.L.W. 2647 (Ohio C.P. Ct., Mar. 21, 1979) (cause of action against landlord for conspiracy to deprive plaintiff of right to enforce rights granted by Ohio landlordtenant laws). 
applications is that imposing civil liability on persons who "conspire or go in disguise on the highway . . . for the purpose of depriving [another] . . . of the equal protection of the laws or of equal privileges and immunities under the laws." "This section of the Act has peculiar significance because it imposes civil liability for deprivations of some federally protected rights against purely private acts. Courts applying the provision must address both the statutory and constitutional limitations of the section 1985(c) cause of action.

To understand the terms of the original Act, and in particular that part of the Act that was codified as section 1985(c), it is necessary to identify the problem it addressed. The prevailing conception of the broad sweep of section 1985(c) can be traced to its origin as a response to the activities of the $\mathrm{Ku}$ Klux Klan. Because the Klan today is thought of as a racist organization, the Ku Klux Klan Act is presumed to afford a remedy for racial or analogous forms of invidious, class-based discrimination. Although this characterization of the Klan is probably accurate today, ${ }^{5}$ it was not true in 1871: the Klan then was primarily a political organization. Understood in the light of its history, the Ku Klux Klan Act was not an antidiscrimination statute. Its drafters intended instead to proscribe conspiracies having the object or effect of frustrating the constitutional operations of government through assaults on the person, property, and liberties of individuals. This comment explores the original meaning of section 2 of the Ku Klux Klan Act and offers reasons why that original intention should govern current construction of section 1985(c).

42 U.S.C. $\$ 1985$ (c) (1976). Section 1985(c) provides in relevant part:

If two or more persons in any State or Territory conspire or go in disguise on the highway or on the premises of another, for the purpose of depriving, either directly or indirectly, any person or class of persons of the equal protection of the laws, or of equal privileges and immunities under the laws; or for the purpose of preventing or hindering the constituted authorities of any State or Territory from giving or securing to all persons within such State or Territory the equal protection of the laws; . . . in any case of conspiracy set forth in this section, if one or more persons engaged therein do, or cause to be done, any act in furtherance of the object of such conspiracy, whereby another is injured in his person or property, or deprived of having and exercising any right or privilege of a citizen of the United States, the party so injured or deprived may have an action for the recovery of damages occasioned by such injury or deprivation, against any one or more of the conspirators.

s See H.R. REP. No. 648, 90th Cong., 1st Sess. 4 (1967) (reprint of the House UnAmerican Activities Committee concerning the $\mathrm{Ku}$ Klux Klan and other organized conspiracies). The present-day Klan was founded in 1915. It borrowed the name, symbolism, and putatively romantic history of the original Klan, which was formally disbanded in 1869 and practically dissolved in 1872. D. Chalmers, Hooded Americanism 19, 30 (1965). 


\section{The Framework of the Section 1985(c) Cause of Action}

Section 1985(c), which comprises only part of the original list of conspiratorial acts prohibited by section 2 of the Ku Klux Klan Act of 1871 , is one of a group of interrelated criminal ${ }^{6}$ and civil ${ }^{7}$ provisions that have descended from the post-Civil War reconstruction statutes. As now codified, section 1985(c) creates a civil cause of action in favor of persons injured in the course of conspiracies having one of four objects: (1) to deprive any person or class of persons of equal privileges and immunities under the laws; (2) to prevent or hinder state authorities from giving or securing to all persons the equal protection of the laws; (3) to prevent by force, intimidation, or threat any voter from giving his support or advocacy in federal elections; or (4) to injure any citizen because of such support or advocacy. ${ }^{8}$ Although the statute enumerates specific conspiratorial objects that fall within its ambit, the key to determining the full reach of section 1985(c) lies in the construction of its language of "equal protection" and "equal privileges and immunities."

Passage of the Ku Klux Klan Act, and in particular section 2,

- See 18 U.S.C. $\$ \S 241,242$ (1976) (providing criminal sanctions for conduct that infringes the civil rights of others). Section 241 was originally enacted as section 6 of the Enforcement Act of 1870, 16 Stat. 141, $\$ 6$ (1870); section 242 was enacted as section 2 of the Civil Rights Act of 1866, 14 Stat. 27, $\$ 2$, and reenacted in amended form as section 17 of the Enforcement Act of 1870,16 Stat. 144, \$ 17 (1870).

7 Civil remedies are clustered in Title 42 of the United States Code. These provisions include section 1981 (protecting "full and equal benefit of all laws and proceedings for the security of persons and property as is enjoyed by white citizens," including the right to contract, be a party in court, and give evidence); section 1982 (prohibiting racial discrimination in transactions in real and personal property); section 1983 (prohibiting the deprivations of constitutional rights by persons acting under color of state law); section 1986 (imposing civil liability on persons who are aware of impending violations of section 1985 , have the power to prevent such violations, and fail to do so). These provisions all resulted from the flurry of civil rights legislation following the Civil War, but did not all have their origins in the same acts and thus do not all share the legislative history of section 1985(c). Section 1981 was originally enacted as section 16 of the Enforcement Act of 1870, 16 Stat. 144, § 16, but had its origins in section 1 of the Civil Rights Act of 1866, 14 Stat. 27, § 1. See H. FriendLy, FEDERAL JURISDiction: A GENERAL VIEW 83 n.41 (1975). Section 1982 was originally enacted as a part of section 1 of the Civil Rights Act of 1866,14 Stat. 27, $\S 1$. Section 1983 was originally enacted as section 1 of the Ku Klux Klan Act of 1871, 17 Stat. 13, § 1. See generally Coffin, Justice and Workability: Un Essai, 5 Surrolk U.L. REv. 567 (1971); Note, Developments in the Law-Section 1983 and Federalism, 90 HARv. L. REv. 1133 (1977). As with section 1985 (c), the courts have generally read these statutes expansively. See, e.g., Johnson v. REA, Inc., 421 U.S. 454, 459-60 (1975) (holding that section 1981 reaches private discrimination); Jones v. Alfred H. Mayer Co., 392 U.S. 409 (1968) (holding that section 1982 reaches private discrimination).

${ }^{8}$ See Collins v. Hardyman, 341 U.S. 651,660 (1951). The first category may be understood as a general statement of prohibited activity, which subsumes the other three more specific cases. See Congressman Garfield's brief explanation of the bill immediately before its final passage. Cong. Globe, 42d Cong., 1st Sess. 807 (1871). 
was motivated by a desire to prevent and punish acts of terror or intimidation that threatened the attempt to create a political environment hospitable to equality. ${ }^{9}$ The scope of activities proscribed by the statute is suggested by the conspiratorial acts enumerated in section 2 of the original Act. These included conspiracies to overthrow or oppose by force the government of the United States, to seize United States property, to injure United States officials on account of or during the discharge of their duties, to deter witnesses or jurors from performing their functions, to hinder the course of justice in state or territorial courts, or to injure any person for enforcing the equal protection of the laws. ${ }^{10}$ Although section 1985(c) does not include all these specific offenses, the full range of conspiracies prohibited by the 1871 Act, taken as a whole, illuminates the original tenor of the language codified in the current statute. That all such conduct giving rise to civil liability under the original section 2 also subjected the conspirators to severe criminal sanctions ${ }^{11}$ is even more suggestive of the intended scope of the provision.

Section 1985(c) lay nearly dormant for a hundred years after its enactment; ${ }^{12}$ as a result, there has been little opportunity for the Supreme Court to construe its language. The authoritative interpretation is to be found in just one case, Griffin $v$. Breckinridge, ${ }^{13}$ decided in 1971. Griffin involved a claim by blacks, one of whom was mistaken for a civil rights worker, who were stopped on the highway by a group of whites, forced from their car, and beaten. ${ }^{14}$ Plaintiffs alleged that the defendants intended to deprive them of various rights, including the rights of speech, assembly, petition, and security of person, property, and liberty. The Supreme Court ruled that the complaint stated a cause of action under section $1985(\mathrm{c}) .^{15}$

- A further means of accomplishing the illegal end is for the conspiracy to attain such size and power that it in effect replaces the legitimate authorities or overthrows them. This danger appeared so serious to the Forty-Second Congress that, in sections 3 and 4 of the Ku Klux Klan Act, 17 Stat. 14, $\$ \S 3,4$ (1871), it provided for the extraordinary remedy of marital law and suspension of habeas corpus to avert it.

1- Id. $\S 2$. Some of these provisions are now codified at 42 U.S.C. $\$ \S 1985$ (a), (b) (1976).

"Section 2 of the Act provided for fines of between $\$ 500$ and $\$ 5,000$, or imprisonment of between six months and six years, or both. 17 Stat. 13, $\$ 2$ (1871). Before being amended during the course of debate, the section provided only criminal penalties. CoNG. GLOBE, 42d Cong., 1st Sess. 317 (1871).

${ }_{12}$ For more complete information regarding the history of section 1985(c) prior to 1971, see Gressman, The Unhappy History of Civil Rights Legislation, 50 Mich. L. REv. 1323, 135557 (1952); Note, The Scope of Section 1985(3) Since Griffin v. Breckenridge, 45 Geo. Wash. L. REv. 239, 240 n.4 (1977); Comment, The Troubled Waters of Section 1985(3) Litigation, 1973 LAW \& Soc. ORD. 639 (1973).

${ }^{13} 403$ U.S. 88 (1971).

14 Id. at 89-91.

is Id. at 106. 
Although the Court's analysis of the application of section 1985(c) did not settle all the vexing questions about the meaning of the section, the Griffin decision provides the basis for all subsequent interpretation. The Court established a two-step method of adjudication of section 1985(c) claims: first, a court must determine whether the defendant's conduct falls within the terms of the statute; ${ }^{16}$ second, it must determine whether Congress has the constitutional power to reach the conduct alleged in the particular case. ${ }^{17}$ The constitutional inquiry focuises upon the power of Congress to regulate the particular acts of the defendants in the case before the court, rather than upon the power to regulate all conduct that could possibly fall within the terms of the statute. ${ }^{18}$ Accordingly, the constitutional authority for the statute will depend on the facts of the particular case. In Griffin the Court found the sources of congressional authority in the power to determine the badges and incidents of slavery under the thirteenth amendment ${ }^{19}$-because the victims were blacks-and in the power to protect the right of citizens to travel among the states ${ }^{20}$ - because the victims may have been engaged in interstate travel when assaulted. Sources of congressional authority in other cases might include the commerce power, ${ }^{21}$ the power to protect rights of national citizenship,,$^{22}$ or the power to protect citizens from deprivation of rights under color of state law. ${ }^{23}$

Analysis of the statutory limits of the cause of action is more complicated. The Griffin Court emphasized that section 1985(c) does not apply to "all tortious, conspiratorial interferences with the rights of others." 24 Rather, the Court identified four elements that must be alleged in order to state a cause of action:

To come within the legislation a complaint must allege that the defendants did (1) "conspire or go in disguise on the highway

16 Id. at $102-03$.

${ }^{17}$ Id. at 104-07.

${ }^{18}$ Id. at 104. In United States v. Harris, 106 U.S. 629 (1882), the Court held unconstitutional the criminal counterpart to section 1985 (c) on a theory that an entire statute must be struck down if any part is unconstitutionally overbroad, unless the different parts could be read as wholly independent provisions. The Griffin Court explicitly rejected this course, 403 U.S. at 104, citing United States v. Raines, 362 U.S. 17, 20-24 (1960).

18 403 U.S. at 104-05.

20 Id. at 105-06. Justice Harlan did not join in this ground. Id. at 107 (Harlan J., concurring).

${ }^{21}$ See, e.g., Novotny v. Great Am. Fed. Sav. \& Loan Ass'n, 584 F.2d 1235, 1255 (3d Cir. 1978) (en banc), rev'd, 47 U.S.L.W. 4681 (U.S. June 12, 1979).

22 See, e.g., Means v. Wilson, 522 F.2d 838 (8th Cir. 1975), cert. denied, 424 U.S. 958 (1976) (right to vote in tribal election).

${ }^{23}$ See, e.g., Cameron v. Brock, 473 F.2d 608 (6th Cir. 1973).

24403 U.S. at 101. 
or on the premises of another" (2) "for the purpose of depriving, either directly or indirectly, any person or class of persons of the equal protection of the laws, or of equal privileges and immunities under the laws." It must then assert that one or more of the conspirators (3) did, or caused to be done, "any act in furtherance of the object of [the] conspiracy," whereby another was (4a) "injured in his person or property" or (4b) "deprived of having and exercising any right or privilege of a citizen of the United States." 25

Since Griffin, courts and commentators have grappled with the meaning of these statutory elements. The two broad questions most vigorously debated are: Which classes of citizens are protected under the equal protection language of the statute ${ }^{26}$ and Which types of injury to plaintiffs may be constitutionally reached by the statute?27 Inadequate attention, however, has been paid to the second element of the cause of action, to the meaning of the words "for the purpose of depriving, either directly or indirectly, any person or class of persons of the equal protection of the laws, or of equal privileges and immunities under the laws." Griffin drew one limitation from this language by emphasizing the word "equal": it is essential to a section 1985(c) cause of action that the conspirators be motivated by a "racial, or otherwise class-based, invidiously discriminatory animus." 28 But courts have failed to give force to the remaining words, which refer not merely to any injury, but to a denial of rights or protection owed to the citizen by the state. Examination of the statute's legislative history reveals that these words are fundamental to the meaning of the statute as enacted.

\section{Legislative History of the Ku Klux Klan Act}

\section{A. The Political Threat of the $\mathrm{Ku}$ Klux Klan}

The violent activities of the Klan and similar organizations ${ }^{29}$

${ }^{25} \mathrm{Id}$. at $102-03$.

26 See note 149 infra.

${ }^{27}$ See, e.g., Action v. Gannon, 450 F.2d 1227 (8th Cir. 1971) (en banc); Dombrowski v. Dowling, 459 F.2d 190 (7th Cir. 1974); Note, supra note 12, at 244-51.

The courts and commentators have also been concerned with one other issue arising under section 1985(c): whether a corporation may conspire with its officers under the terms of the Act. Compare Novotny v. Great Am. Fed. Sav. \& Loan Ass'n, 584 F.2d 1235 (3d Cir. 1978) (en banc), rev'd, 47 U.S.L.W. 4681 (U.S. June 12, 1979), with Herman v. Moore, 576 F.2d 453 (2d Cir. 1978) and Baker v. Stuart Broadcasting Co., 505 F.2d 181 (8th Cir. 1974). See Note, Intracorporate Conspiracies Under 42 U.S.C. $\$ 1985(c), 92$ HARv. L. REv. 470 (1978). 
caused great alarm among the members of the Forty-Second Congress. They occasioned debates during the first session that now fill hundreds of pages of the Congressional Globe and caused Congress to establish a joint committee to investigate the Klan. ${ }^{30}$ The Republicans especially found Klan violence troubling because they were convinced that it was politically motivated. Such is the conclusion stated in the majority report of the Senate Select Committee to Investigate Alleged Outrages in the Southern States: "[I]t is clearly established .... [t]hat the $\mathrm{Ku}-\mathrm{Klux}$ organization does exist, has a political purpose, is composed of members of the democratic or conservative party, [and] has sought to carry out its purpose by murders, whippings, intimidations, and violence."31 This theme was sounded again and again during the debates in Congress, the Republicans steadily insisting on it $^{32}$ and the Democrats stead-

reconstruction South. Others included the Knights of the White Camelia, the White Brotherhood, the Pale Faces, and the '76 Association. K. Stampr, The ERA of Reconstruction 199 (1965).

30 The Committee called hundreds of witnesses, took thousands of pages of testimony, and eventually issued a mammoth, thirteen-volume report. S. REP. No. 41, 42d Cong., $2 d$ Sess. (1872). Cf. Avins, The Ku Klux Klan Act of 1871: Some Reflected Light on State Action and the Fourteenth Amendment, 11 ST. Louls U.L. REv. 331 (1967) (discussing original purpose of fourteenth amendment). See also H. Flack, The ADOPTION OF THE FourteENTH AMENDMENT 210-77 (1908).

${ }^{31}$ H.R. REP. No. 1, 42d Cong., 1st Sess. xxx-xxxi. According to its report, the Committee was appointed for the following purposes: "[T] ascertain by investigation - First, whether crimes of the character alleged have been committed by organized bands of a political character; Second, whether persons and property are secure in the Southern States." Id. at ii. The Klan membership oath included a commitment to "oppose all radicals and negroes in all of their political designs." Id. at xiv-xv. In regard to the first of the above-stated inquiries the Committee concluded as follows: "With the testimony and the terms of this oath before him, no reasonable man can doubt that the purpose of this organization was political. "Id. at xv. Furthermore, as Congressman Shellabarger pointed out in debate, the minority report inadvertently admitted that the Klan was politically motivated: "[T]he minority of the committee reach the same conclusion as the majority reach as to the fact that the disorders have a political origin and purpose, the difference being, in substance, that the majority find it to originate in an aim at the overthrow of these reconstruction laws and the people and State governments they were designed to protect, while the minority seem to conclude that the violence is natural and just in resistance of wicked laws." Cong. GloBE, 42d Cong., 1st Sess. 517, col. 2 (1871) [The debates on the Ku Klux Klan Act will hereinafter be cited as Cong. GLOBE, with page and column references].

Congressman Shellabarger's characterization of the Democrats' position is basically accurate. See, e.g., CoNg. GLOBE, supra, at 386, col. 2 (remarks of Congressman Lewis (DKy.))("But, sir, when you consider the actual condition of the people of the South now and ever since the war; that the control of governmental affairs has been kept out of the hands of the wise, virtuous, influential men of the South, and given to adventurers and negroes; . . . must not disorders and disturbances exist to some extent, and will they not continue to exist as long as the unnatural and disgusting causes exist?"); id. at app. 91, col. 1 (remarks of Congressman Duke (D-Va.); id. at 416, col. 1 (remarks of Congressman Biggs (D-Del.)).

${ }^{32}$ With one exception, all the Republicans who addressed the question whether the Klan 
fastly denying it. ${ }^{33}$

The immediate goal of the Klan, as seen by the Republican majority, was to wrest control of the state governments from the Republican party and to reestablish Democratic hegemony in the South. ${ }^{34}$ The Republicans perceived two different ways in which the Klan might seize power in the states. The first was by means of political terrorism-including harassment of Republican voters and murder of the leaders of the Republican party-that would ensure the success of Democratic candidates at the polls. Congressman Stoughton, for example, summarized the Klan's tactics as follows: "The murder of leading Republicans, terrifying the colored population, and putting whole neighborhoods in fear so that the $\mathrm{Ku}$ Klux

was a political organization concluded that it was. The exception was Congressman Monroe, of Ohio, who raised the question but left it unanswered. Cong. GLOBE, supra note 31, at 369, col. 3. Congressman Stoughton gave one of the most detailed discussions of the Klan's political nature. Id. at 320-22. See also the remarks of Congressmen Hoar (R-Mass.), id. at 333, col. 3 ("secret political conspiracy"); Elliott (R-S.C.), id. at 391, col. I ("the design of the Ku Klux is political"); Roberts (R-N.Y.), id. at 412, col. 3, 413, col. 1 ("the organization . . . is political in its origin and aims . . . . [T] persons are mutilated, whose lives are sacrificed, are always Republicans."); McKee (RMiss.), id. at 426, col. 3 ("The dead and the wounded, the maimed and the scourged, are all, all Republicans."); Cobb (R-N.C.), id. at 437, col. 2 ("every victim of Ku Klux outrage has been a Republican"); Butler (R-Mass.), id. at 443, col. 1 (Klan is a "political engine in the hands of the [Democratic party]"); Coburn (R-Ind.), id. at 457, col. I (Klan is "political in its nature"); Wilson (R-Ind.), id. at 484, col. 1 (purpose of Klan is "to get possession of local and State governments"); Lansing (R-N.Y.), id. at 488, col. 1 ("the Ku Klux in their crimes are inspired by political zeal"); Blair (R-Mich.), id. app., at 72, col. 2 ("they murder for a difference in political opinions"); Perry (R-Ohio), id. app., at 78, col. 3 (Klans are "organizations in aid of the Democratic party"); Snyder (R-Ark.), id. app., at 196, col. 2 (the "object [of the Klan is] the defeat of Republicanism"); and Burchard (R-Ill.), id. app., at 312, col. 2 ("through their agency the lives and persons of political opponents are doomed to violence and outrage").

Republican Senators were in accord. See, for example, the remarks of Senators Pratt (RInd.), id. at 504, col. 1 (the leading purpose of the Klan "is to punish men for their political opinions"); Edmunds (R-Vt.), id. at 702, col. 1 (the "systematic plan [of the Klan] is not to leave in any of those States a brave white man who dares to be a Republican or a colored man who dares to be a voter"); Pool (R-N.C.), id. app., at 108, col. 1 (the Klan "is a Democratic organization, in the interests of the Democratic Party"); and Morton (R-Ind.), id. app., at 252, col. 1 ("[T] he purpose [of the Klan] is by these innumerable and nameless crimes to drive those who are supporting the Republican party to abandon their political faith or to flee from the State.")

${ }^{33}$ See, for example, the remarks of Congressmen Morgan (D-Ohio), id. at 330-31; Bayard (D-Del.), id. app., at 17-19; and Vaughn (D-Tenn.), id. app., at 139-40.

3 Republican Senator Osborn of Florida, for example, stated that the Klan's "well defined and clearly proven object is to gain political control by intimidation and murder." Id. at 653, col. 3; accord, id. at 484, col. 1 ("And, sir, what is the purpose of all this bloody work? I assert . . . that it is for the express purpose of controlling governments in the States") (remarks of Congressman Wilson (R-Ind.)). Most historians support the Republicans' perception. See, e.g., D. Chalmers, supra note 5, at 10-21; J.H. Frankin, RrconSTRUCTION (1961). 
can control an election, is heralded as a Democratic victory." 35 The second way in which the Republicans feared the Klan might seize power in the states was by supplanting the authority of elected state officials, ${ }^{36}$ allowing the Klan to control the state regardless of the party affiliations of state executive officials, judges, and legislators.

Republican officeholders were in particular danger of the Klan's political terrorism. Senator Osborn, for example, cited cases of the assassinations within a single year of two successive clerks of the Court of Jackson County, Florida, both of whom were Republicans. In addition to these two, Osborn asserted, "seventy-two others have fallen by assassination in the same county, all Republicans, and yet no criminal has been punished for this slaughter." 37 Congressman Snyder of Arkansas reported similar incidents that occurred in 1868, when he was a state senator: during a three month recess, five Republican state senators were victims of assassination attempts. ${ }^{38}$

Ordinary voters, as well, were in danger from the Klan, not because they were black, but because they were Republicans. To illustrate this fact, Congressman Stoughton quoted the testimony of Caswell Holt, whom he described as "a poor and ignorant, but honest and conscientious negro, who was twice visited by the Ku Klux." Holt said that the "colored people" of his country did not feel safe, that the Klansmen "wanted to run them all off because the principal part of them voted the Radical ticket." He stated that no persons were "bothered at all that voted the Conservative ticket." 39

35 Cong. Grobe, supra note 31 , at 321 , col. 2.

${ }^{36}$ See, e.g., id. at 487, col. 3 ("disorders are so great in some of the States as to paralyze the power of the local authorities.") (remarks of Congressman Tyner (R-Ind.)); id. app., at 72 , col. 2 ("the Klans are powerful enough to defy the state authorities . . . The states are prostrate before a power they cannot control.") (remarks of Congressman Blair (R-Mich.)); id. app., at 196, col. 2 ("even now they are so powerful as to control State authority and prevent the execution of the laws.") (remarks of Congressman Snyder (R-Ark.)).

37 Id. at 654 , col. 1 .

${ }^{33}$ Id. app., at 200, col. 1. Congressman Shellabarger, the sponsor of the bill, cited in lurid language several prominent instances of Klan violence designed to secure the election of Democratic candidates:

So it was in 1866, when a Republican State convention, engaged in the formation of a free constitution was murdered or dispersed. So it was again in 1868, at New Orleans; by blood they carried the State for Seymour. So in 1866, at Mobile, Alabama, a single unprovoked volley fired by Ku Klux Democrats into a political meeting of Republicans killed or wounded more voters than was the majority of a State legislator whose vote elected to the Senate of the United States one member of that illustrious body, now making our laws from a seat dripping with innocent human gore . . . . . So it was in 1868, at Camilla, Georgia, where a Republican convention was murdered and the State given by organized slaughter to Seymour.

Id. at 517 , col. 2.

30 Id. at 321, col. 1 (quoting H.R. REP. No. 1, 42d Cong., 1st Sess. 345 (1871)). 
Holt's observation was corroborated by that of Congressman Buckley of Alabama, a Republican: "Nor does this Ku Klux business take its origin in the antagonisms of race. White and black suffer alike; more colored than white, because the colored are the most numerous." 40

The ultimate goal of the Klan's usurpation of power through terror and political subversion, the Republicans believed, was to overthrow reconstruction policy, including the recent amendments to the Constitution, thereby withdrawing from the freedmen the equal protection of the laws and equal privileges and immunities that policy secured. In the final speech before the Ku Klux Klan Act was first approved by the House, Congressman Shellabarger outlined the Klan's long-range plans:

Mr. Speaker, that I may make absolutely and utterly irresistible the proofs that these banded conspirators have the political aims I attribute to them, to wit, to "trample into dust" these newly-acquired political rights of the freed men and the constitutions and laws which confer them, I now call new and distinguished witnesses. Take this one first, that the Democratic party of this nation, 4th July, 1868, in national platform, formally and solemnly announced ... that "we regard the reconstruction acts (so called) of Congress, as such, as usurpations and unconstitutional, revolutionary, and void."'41

\section{B. The Congressional Response}

Although the Republicans in the House ${ }^{42}$ were unanimous in their identification of the problem that the legislation was to

4Id. app., at 194, col. 3 .

"Id. at 517, col. 3. See also Congressman Shellabarger's entire speech. Id. at 516-19. Accord, id. app., at 195, col. 1. ("It seeks to strike down your reconstruction laws and reduce the newly enfranchised race to a non-voting population.") (remarks of Congressman Buckley (R-Ala.)); id. app., at 201, col. 1 (object of Klan is the "overthrow of the whole system of reconstruction") (remarks of Congressman Snyder (R-Ark.)). This view is corroborated by the testimony of the Democrats themselves: "No, sir; if lawlessness exists it results from the government set over them; it is the legitimate offspring of reconstruction." Id. at 421, col. 1 (remarks of Congressman Winchester (D-Ky.)).

12 The analysis here of the legislative history will focus exclusively on the House debates, for it was in the House that the eventual compromise was reached that is now reflected in section 1985 (c). The Senate debate covered the activities of the Klan in great detail and also covered constitutional issues discussed by the House. Id. at 691-96 (remarks of Senator Edmunds (R-Vt.)). Much of the Senate debate centered on an amendment introduced by Senator Sherman that would have imposed liability on counties and municipalities for injuries sustained by victims of Klan-like activities. For a summary of the Senate debates, see Avins, supra note 30 , at 358-71, 375-76. 
address, there was substantial disagreement within their ranks when it came time to fashion a solution. This disagreement arose largely out of their differing interpretations of the extent of congressional power under the fourteenth amendment. ${ }^{43}$ With one exception, ${ }^{44}$ all agreed that Congress should do everything in its power to combat the Klan. ${ }^{45}$ Thus, two proposed solutions-the bill as originally introduced and the bill as amended during the course of debate-reflected the two principal conflicting views of the scope of congressional power under the fourteenth amendment: those who considered federal powers to be far-reaching favored far-reaching measures, and those who held more conservative views of the Constitution supported more conservative measures. The key to understanding the scope of the Act, therefore, lies in understanding the view of the congressional power under the fourteenth amendment that ultimately prevailed in the Congress that passed the Act. ${ }^{46}$

1. The Radical Republican View. The Republicans were divided on the question of the extent of federal powers. ${ }^{47}$ The position of the more radical Republicans may best be illustrated by considering the bill as it was first introduced. In the initial bill, section 2 provided criminal sanctions for conspiracies to commit certain enumerated crimes "in violation of the rights, privileges, or immunities of any person, to which he is entitled under the constitution and laws of the United States."48 Although more moderate Republicans opposed this measure as an unconstitutional usurpation of the

43 Except for the most radical among the Republicans, see text and notes at notes 47-53 infra, all assumed that Congress was acting under the fourteenth amendment; indeed, the Act was entitled "An Act to enforce the provisions of the Fourteenth Amendment to the Constitution of the United States, and for other purposes." CoNG. GLoBe, supra note 31, at 335 , col. 3 .

i Congressman Sheldon, a Louisiana Republican who voted for the amended bill, stated that he believed in "large powers" of the federal government, but that he did not "by any means advocate the wisdom or expediency of their exercise at all times." Id. at 368, col. 2.

15 Congressman Willard said: "We may go to the extent of the powers granted; we cannot go one step beyond." Id. app., at 187, col. 3; accord, id. app., at 312, col. 3 ("the extreme verge of fair construction that will justify Federal intervention") (remarks of Congressman Burchard (R-IIl.)).

46 The constitutional views of the Forty-Second Congress are not authoritative, except insofar as they reflect the original intention of the fourteenth amendment. See Avins, supra note 30 . The constitutional views of the Congress nevertheless are highly relevant to interpreting the statute that they passed, since it was tailored to comply with constitutional limitations as they understood them.

$1^{17}$ The Democrats were united in their opposition to the bill, thus giving the balance of power to the moderate Republicans. The most authoritative interpretations of the bill, therefore, are those of the moderate Republicans who opposed the original version presented by Congressman Shellabarger, but who supported the amended version.

is Cong. GloBe, supra note 31, app., at 188, col. 1, 206, cols. 1-2. 
states' power to punish crime ${ }^{49}$ some members of Congress defended it on a theory based more on a perceived need for such power than on provisions of the Constitution. For example, Congressman Austin Blair, a Michigan Republican, said:

We cannot indulge much in constitutional hair-splitting while citizens of the United States are denied the right to live. It will not do to be over particular as to the matter of whose duty it is to protect the citizens against armed bands of assassins who will not wait for our decisions. It ought to be the duty of both the State and the nation to do this; and if the State will not, the nation must. ${ }^{50}$

Representative Shanks, another radical supporter of the bill as originally introduced, relied on a vague claim that the Civil War had altered the disposition of powers between the federal and state governments. The Civil War, he said, had "settled forever the right of the citizen to protection by the national Government, despite the treason of the Democratic statesmen who had long taught a different doctrine." ${ }^{11}$

Other supporters of the original version of section 2 justified it on a more restrained basis. Their position was that the federal government may protect citizens in the enjoyment of federal rights against the attacks of private individuals. Congressman Shellabarger, House sponsor of the bill, staunchly denied that it reached ordinary crimes, and agreed that the federal government had no power to assume a general criminal jurisdiction. He defended the bill as a measure to protect fourteenth amendment rights, and said that the "mentioning" of particular crimes was intended to enumerate the "limitations" of the reach of the statute. ${ }^{22}$ Congressman Hawley's reasoning was similar. He agreed that the federal govern-

1 Typical of their objections is the statement of Congressman Burchard of Illinois that "if [section 2] intends and must be construed to give the Federal courts jurisdiction to punish combinations or conspiracies to commit murder, mayhem, assault and battery within a State, I can find in the Constitution no warrant for the exercise of such authority." Id. app., at 313 , col. 2; accord, id. at 485 , col. 2 ("I do not believe . . . that Congress has a right to punish an assault and battery when committed by two or more persons within a state.") (remarks of Congressman Cook (R-Ill.)); id. at 514, col. 1 (remarks of Congressman Poland (R-Vt.)); id. app., at 112, col. 2 (remarks of Congressman Moore (R-Ill.)).

${ }^{50}$ Id. app., at 73, col. 2; accord, id. at 395, col. 1 ("I take the ground that, in my opinion, lies far above the interpretation put upon the provisions of the Constitution. I stand upon the broad plane of right ....") (remarks of Congressman Rainey (R-S.C.)); id. at 512, col. 2 ("The Constitution is compatible with the enforcement of peace, good order, and domestic tranquility, or it is not worth the saving.") (remarks of Congressman Perce (R-Miss.)).

${ }^{51}$ Id. app., at 141, col. 3.

${ }^{32}$ Id. at 382 , col. 3 . 
ment could not punish ordinary criminals. But, he asserted, when faced with a conspiracy to prevent a citizen from exercising rights such as the right to vote or to hold office, the government should say: "If you stand in the way of the exercise by this man of the rights and privileges to which he is clearly entitled ...., and in pursuance of such combination or conspiracy shall take life, then you shall forfeit your life to the Government of the United States as a punishment ...." ",53

2. Moderate Republican Responses. The moderate Republicans who opposed the original version of section 2 consistently denied that the federal government had an unlimited right to intervene on behalf of citizens whose rights were violated by private individuals. ${ }^{54}$ These moderates differed, though, in their estimation of the proper scope of congressional power over the conduct of private persons. With few exceptions, ${ }^{55}$ there was little argument about whether the federal government could prescribe punishment for state officials whose actions deny equal protection..$^{56}$ Nor was there significant doubt that Congress could, in some circumstances, prescribe punishment to be imposed directly upon private individuals. But the moderates who opposed the original version of section 2 disagreed on what those circumstances were.

The moderates located the source of the authority to reach private conduct in the congressional power to protect the rights of national citizenship. ${ }^{57}$ Congressman Cook, the Illinois Republican who suggested to the Committee the limiting amendment that was ultimately adopted, gave as an example a hypothetical case in which private persons conspire to prevent a state court clerk from

${ }^{33}$ Id. at 383, col. 1; accord, id. at 332, col. 2 (remarks of Congressman Hoar (R-Mass.)).

st See text and note at note 49 supra.

ss One Congressman, Farnsworth of Illinois, argued that the federal power could never extend to individuals under the fourteenth amendment, whether or not they were public officials. He believed that the amendment served only to strike down "unjust, discriminatory, partial legislation." CoNG. Globe, supra note 31, app., at 115, col. 3. Accordingly, he introduced an amendment that would have confined the section to conspiracies interfering with federal officers in their enforcement of equal protection. Id. at 513, col. 2. He later withdrew the amendment and voted for the final bill. See id. at 515, col. 2; 522, col. 1 .

s6 The principle is the basis of section 1983, which was enacted as section 1 of the Act. This section occasioned almost no controversy during the debates.

${ }^{57}$ Id. at 485, col. 2 (remarks of Congressman Cook (R-Ill.)). This opinion was common ground among the Republicans. According to Congressman Shellabarger, the enforcement clause of the fourteenth amendment authorized Congress "to directly protect and defend throughout the United States those privileges and immunities which are in their nature 'fundamental' - and I use my words cautiously when I say 'in their nature fundamental'and which inhere in and belong of right to the citizenship of all free Governments." Id. app., at 69 , col. 1 . 
certifying to the Supreme Court a state court decision denying a claim based on a federal right. Since certiorari from the Supreme Court in such a case is a right of national citizenship, these conspirators could be punished by the federal government. ${ }^{58}$ More generally, Congressman Cook asserted that the rights of national citizenship encompass the right to equality of treatment conferred by the fourteenth amendment: "The amendment provides that no State shall deny to any portion of its citizens the equal protection of the laws. That is the right which the Constitution secures to every citizen of the United States . . . . " 59 This right, too, may be protected against conspiracies of private persons:

[E]very combination of men . . . to induce the Legislature of a State by unlawful means to deprive citizens of the equal protection of the laws, or to induce the courts to deny citizens the equal protection of the laws under the Constitution of the United States is the offense against the Constitution of the United States, and may be defined and punished by national law. And that, sir, is the distinct principle upon which this bill is founded. ${ }^{60}$

This statement of Congressman Cook exemplified the theory of one group of moderates, who viewed the government's power as narrowly circumscribed. They believed that Congress may prescribe punishment for only those private conspiracies intended to obstruct the performance of government officials' constitutional duty to provide equal protection of the laws. Congressman Burchard, for example, described as "few and restricted" the powers of the federal government to remedy the neglect or refusal of a state to perform its constitutional duties. He stoutly denied that the federal government can "perform the duty the Constitution enjoins upon the State." Rather, he said, the federal government is limited to requiring state officials to perform their duties and punishing "the illegal attempts of private individuals to prevent the performance of official duties in the manner required by the Constitution and laws of the United States."

Some moderate Republicans adhered to a broader view of congressional power: they believed that the federal government could intervene to provide protection for individual citizens against pri-

\footnotetext{
${ }^{38}$ Id. at 486 , col. 3.

ss. Id.

$\omega$ Id.

"Id. app., at 314, col. 3.
} 
vate conspirators when the states failed to do so. According to Congressman, later President, Garfield,

[T] he chief complaint is not that the laws of the State are unequal, but that even where the laws are just and equal on their face, yet, by a systematic maladministration of them, or a neglect or refusal to enforce their provisions, a portion of the people are denied equal protection under them. Whenever such a state of facts is clearly made out, I believe [the fourteenth amendment] empowers Congress to step in and provide for doing justice to those persons who are thus denied equal protection. ${ }^{62}$

The moderates adopting this view described the occasions when state inaction constitutes a denial of equal protection in different ways: Congressman Garfield referred to "systematic maladministration," or "neglect or refusal"; Congressman Perry referred to state authorities "in complicity with" the conspirators. ${ }^{63}$ The moderates disagreed over the question whether the requisite state inaction need be caused by the complicity of state officials, their inability to maintain control, or their mere neglect; but they agreed that primary jurisdiction over the protection of the life, liberty, and property of citizens lies with the states. Only in the case of established failure of the states to provide equal protection may the federal government intervene.

Thus, the moderates who adhered to the view expounded by Garfield opposed the original draft of section 2 on the ground that its reach was not confined to those cases in which the state failed to perform its duty: the original section would have provided a

2 Id. app., at 153, col. 3; accord, id. at 459, col. 2 (remarks of Congressman Beatty (ROhio)); id. app., at 80, col. 2 (remarks of Congressman Perry (R-Ohio)). Congressman Bingham, author of section 1 of the fourteenth amendment, may have held this view as well. See id. app., at 85, col. 2 (reconciling the fourteenth amendment's nature as a limitation on state conduct with the bill's punishment of private behavior).

Congressman Hoar also agreed that the congressional power to provide protection to citizens from the actions of private individuals existed only when "these evils have attained such a degree as amounts to the destruction, to the overthrow, to the denial to large classes of people of the blessings of republican government altogether." Id. at 334, col. 1. He nevertheless supported the original version of section 2, because the Klan depredations were proven so serious as to provide such constitutional justification. He did not, though, expect that the statute would remain on the books. "Now this measure . . . will, I trust, be short-lived." Id. at 335 , col. 2. He thus did not share Congressman Garfield's constitutional reservations.

as Id. at 79, col. 3; accord, id. at 481 , col. 1 ("if it be true that a State can willfully withhold the execution of her laws with reference to the protection of particular individuals or a particular class of individuals") (remarks of Congressman Wilson (R-Ind.)); $c f$. id. at 485, col. 2 ("combinations too strong for the State authorities to put down or subdue") (remarks of Congressman Cook (R-Ill.)). 
federal remedy for invasion of rights whether or not the state was willing and able to protect them. They insisted that the section be limited to instances of clear state failure to meet its constitutional obligations. As Congressman Garfield said:

Now if the second section of the pending bill can be so amended that it shall ... not in any way assume the original jurisdiction of the rights of private persons and of property within the States-with these conditions clearly expressed in the section, I shall give it my hearty support. These limitations will not impair the efficiency of the section, but will remove the serious objections that are entertained by many gentlemen to the section as it now stands. ${ }^{64}$

\section{The Amended Bill}

The debate among the moderates over the circumstances in which the federal government might reach the conduct of private conspirators continued until passage of the final version of the Act. ${ }^{65}$ They agreed, however, that the original version of section 2 was unconstitutional and that the amended version-suggested by Congressman Cook, drafted by Congressman Willard, and explained by Congressmen Wilson, Poland, and Burchard-satisfied their constitutional objections. The limiting amendment substituted the language now found in section 1985(c), proscribing conspiracies with "the purpose of depriving any persons or class of persons, directly or indirectly, of the equal protection of the laws, or of equal privileges and immunities under the laws." "66 The amendment also added a civil right of action to the criminal sanctions of section 2 . This additional remedy was not a subject of congressional discussion or debate. It was presumably inspired at least in part by concern for the victims of acts of terror or indirect subversion committed to inhibit the exercise of the rights of citizens.

"Id. app., at 153, col. 3 .

is The debate is best summarized by Congressman Poland of Vermont:

I cannot agree with several gentlemen on my side of the House who insist that if the State authorities fail to punish crime committed in the State therefore the United States may step in and by a law of Congress provide for punishing that offense; I do not agree with those gentlemen.

But I do agree that if a State shall deny the equal protection of the laws, or if a State make proper laws and have proper officers to enforce those laws, and somebody undertakes to step in and clog justice by preventing State authorities from carrying out this constitutional provision, then I do claim that we have the right to make such interference an offense against the United States.

Id. at 514 , col. 1 .

' Id. at 477 , col. 3 . 
One obvious change in the meaning of section 2 wrought by this substituted language was to confine the operation of the section to discriminatory deprivations of rights. As explained by Congressman Willard, the "essence" of the conduct proscribed by the section is "the intent to deprive a person of the equal protection of the laws and of equal privileges and immunities under the laws; in other words, ... . the Constitution secured, and was only intended to secure, equality of rights and immunities." 67 This change was not made in response to any specific criticism of the original draft, and it is therefore mysterious that the change appeared unheralded at that stage of the debate.

It is important to understand that the moderates who opposed the original bill on constitutional grounds supported the amended version because they thought that the language of "equal protection" and "equal privileges and immunities" confined the reach of the section to deprivation of rights through the channels of government. Congressman Burchard's summary of the amended bill shows that this was the purpose of the limiting amendment. ${ }^{68} \mathrm{He}$ explained that the conspiracies within the ambit of the section were "those designed to prevent the equal and impartial administration of justice. . . . The gravamen of the offense is the unlawful attempt to prevent a State through its officers enforcing in behalf of a citizen of the United States his constitutional right to equality of protection." ${ }^{69}$ Congressmen Cook, ${ }^{70}$ Farnsworth, ${ }^{71}$ and Poland ${ }^{72}$ echoed Burchard's analysis of the amended bill. It is therefore evident that

"Id. app., at 188, col. 2 (emphasis added). In a similar vein, Congressman Shellabarger said that

the object of the amendment is, as interpreted by its friends who brought it before the House . . . to confine the authority of this law to the prevention of deprivations which shall attack the equality of rights of American citizens; that any violation of the right, the animus and effect of which is to strike down the citizen, to the end that he may not enjoy equality of rights as contrasted with his and other citizens' rights, shall be within the scope of the remedies of this section.

Id. at 478, col. 2; accord, id. at 315, col. 2 ("It is not denial of protection, which constitutes the offense against the United States.") (remarks of Congressman Burchard (R-Ill.)). This aspect of the limiting amendment was effectuated by the discriminatory animus requirement set forth in Griffin v. Breckenridge, 403 U.S. 88, 101-02 (1971). The Court relied on the quoted statements of Congressmen Willard and Shellabarger.

as Cong. Globe, supra note 31, app., at 315, col. 2.

"Id. col. 2.

70 Id. at 486 , col. 3 .

"Congressman Farnsworth considered even the amended section 2 to go too far, and therefore proposed a further limiting amendment. "Unless this amendment is made, that is what this section does; for it provides that if any person shall resist the constituted authorities of the State his case shall be sent to the United States court." Id. at 513, col. 3.

72 Id. at 514, col. 3 . 
these moderates supported the amended version of the bill because they believed that it complied with their theory that private conspirators could be punished by the federal government only if they acted to frustrate a government official in the performance of his constitutional responsibility.

Congressmen Garfield and Willard and the other moderates who believed that Congress could constitutionally intervene to provide protection when the state government failed to do so also supported the amended bill. Although the language of the amendment does not explicitly reflect their position, it is possible that they understood it to do so. Congressman Willard, for example, took credit for drafting the limiting amendment. With the amendment, he "cheerfully" gave the section his support, even though he was one of the congressmen who took the broader position on the scope of the fourteenth amendment. ${ }^{73}$ Congressman Garfield and his fellows may have believed that their position was impliedly expressed in the amended section, or they may have chosen to support a measure that did not exert what, in their view, was the full extent of Congressional power. Their reasons for supporting the amended bill, however, are largely irrelevant to present-day application of the statute, since contemporary section 1985 (c) claims do not allege that state governments are unwilling or unable to provide protection. ${ }^{74}$ In the absence of such an allegation, the positions of the moderates converge: the statute reaches private conspiracies to frustrate the provision by governmental officials of equal protection of the laws.

It would be a mistake to read this legislative intent as limited to direct interference with government provision of equal protection. Just as the depredations of the Klan frequently involved no component of direct obstruction of officials, so also modern applications of the statute should be able to reach indirect efforts to thwart equal protection. The Ku Klux Klan was a political conspiracy; its depredations frequently involved no component of direct obstruction of officials. The Klansmen's object was to seize control of state governments, to reverse the process of reconstruction, and to nullify the rights recently conferred upon the freedmen by the thirteenth, fourteenth, and fifteenth amendments. Their primary weapon was polit-

${ }^{73}$ Id. app., at 188, col. 2. See also the remarks of Congressman Wilson, who noted that the amended bill posed the problem of "whether or not Congress possesses the constitutional power to enact laws securing to the citizens in a State the equal protection of the laws, where the State fails to do so through inability to execute the laws. "Id. at col. 1. Wilson ultimately concluded, with Congressmen Garfield and Willard, that Congress does have such power.

"Perhaps in some unusual circumstances the claim could be made; no modern plaintiff has tried. 
ical terror, directed especially against those whose votes and efforts sought to bring about just and impartial state administration. In this way they hoped to make it politically impossible for the states to accord equal protection. The moderates who drafted the statute were careful not to curtail the effect of the general clause of section 2 by words such as "obstructing a governmental official." Rather, they employed the phrase "directly or indirectly" to insure that the statute would reach the schemes of conspirators designed to block equal protection by indirect and political means.

\section{Supreme Court InTERPRETAtion}

Although the legislative history reveals that Congress intended section 1985(c) to reach conspiracies to obstruct government officials from providing equal protection of the laws, the question remains whether the Supreme Court has adopted this conception of the purpose of the statute. The few significant Supreme Court decisions concerning section 1985 (c) have reached widely divergent conclusions about the scope of the statute's coverage and its constitutionality as construed.

\section{A. Supreme Court Doctrine Prior to Griffin}

Examination of the Court's treatment of section 1985(c) must begin with United States $v$. Harris ${ }^{75}$ decided in 1876, which held unconstitutional the criminal provisions of section 2 of the Ku Klux Klan Act. In Harris, the Court accorded the statute a broad construction and held that so construed the statute exceeded the powers of Congress. ${ }^{76}$ The Court correctly concluded that the statute reached conduct of private persons, ${ }^{77}$ but followed a curious line of reasoning from this premise to the conclusion that the statute was unconstitutional. "The only way," the Court said, "in which one private person can deprive another of the equal protection of the laws is by the commission of some offense against the laws which protect the rights of persons, as by theft, burglary, arson, libel, assault, or murder."78 Fearing that the statute would "invest Con-

75106 U.S. 629 (1882).

7 The Court analyzed possible sources of congressional authority found in article IV, section 2 , and the thirteenth, fourteenth, and fifteenth amendments. In contrast to the mode of constitutional adjudication employed in Griffin, see 403 U.S. 104; text and note at note 18 supra, the Harris Court followed a severability rule that required the statute to be struck down if any part of it is constitutionally overbroad. See 106 U.S. at 641-42.

${ }^{77} 106$ U.S. at 637-39.

${ }^{78}$ Id. at 643 . 
gress with power over the whole catalogue of crimes," the Court struck it down. ${ }^{79}$

The Court's analysis is confusing since it relied on a theory that was apparently recognized and deflected by the enacting Congress. The supporters of the amended version of section 2 anticipated the Harris Court's conclusion that Congress has no power to assume a general criminal jurisdiction; ${ }^{80}$ it was precisely in order to avoid that unconstitutional result that the statute was amended to limit its reach to conduct intended to frustrate equal protection of the laws. The Harris Court seemingly ignored the amendment and decided the case as if it were interpreting the original version of the statute introduced by Congressman Shellabarger. ${ }^{81}$ The Court's interpretation disregards the plain language of the statute:82 private persons are considered to deprive others of the equal protection of the laws by "preventing or hindering the constituted authorities . . . from giving or securing to all persons . . . equal protection of the laws." It is no more implausible to say that private persons may accomplish the same end indirectly by spreading terror, securing illegitimate victory at the polls, or suppressing the political activity of persons who seek to induce the state to rectify denials of equal protection.

After Harris, the next significant pronouncement of the Court came 70 years later in Collins $v$. Hardyman. ${ }^{84}$ Collins involved the disruption of a political meeting protesting the Marshall Plan by a group of persons wearing American Legion hats. The disruption, described by the Court as a "lawless political brawl, precipitated by a handful of white citizens against other white citizens," 85 involved no attempt by conspirators to affect the state's provision of equal

\footnotetext{
"Id.

See text and notes at notes 54-64 supra.

81 See text and notes at notes 47-53 supra.

${ }^{32}$ See McLellan v. Mississippi Power \& Light Co., 545 F.2d 919, 936-38 (5th Cir. 1977) (Godbold, J., dissenting).

ss 42 U.S.C. $\$ 1985$ (c) (1976).

341 U.S. 651 (1951). The Court decided two other cases involving section 1985(c)
} between Harris and Collins, but the interpretations in those cases are not illuminating here. Snowden v. Hughes, 321 U.S. 1 (1944), held that in a suit brought to enforce the fourteenth amendment through section 1985(c), "privileges and immunities" consist of rights incident to national, not state, citizenship and that "equal protection" violations require discrimination, id. at 6-8. Tenny v. Brandhove, 341 U.S. 367 (1951), held a section 1985(c) action barred by official immunity. A third case, Hague v. CIO, 307 U.S. 496 (1939), is sometimes cited as relying on the predecessor to section 1985(c). See, e.g.., Novotny v. Great Am. Fed. Sav. \& Loan Ass'n, 584 F.2d 1235, 1239 n.10 (3d Cir. 1978) (en banc), rev'd, 47 U.S.L.W. 4681 (U.S. June 12, 1979). Actually, the Court decided Hague under the precedessor to section 1983. 
protection, either directly or indirectly. ${ }^{86}$ The Court explicitly noted that there was "not the slightest allegation that defendants were conscious of or trying to influence the law, or were endeavoring to obstruct or interfere with it."

The precise holding of the case is difficult to discern. The Ninth Circuit, reversing the district court, had held that section 1985(c) is not limited to invasions of civil rights under color of state law; ; $^{88}$ the Eighth Circuit had previously reached the opposite conclusion..$^{89}$ Although the Supreme Court granted certiorari to resolve the conflict, ${ }^{90}$ in fact the Court did not resolve the constitutional issue addressed by the courts below. ${ }^{91}$ Instead, the Court apparently rested its decision on nonconstitutional grounds, concluding that the plaintiffs had not been the victims of "a conspiracy to alter, impair or deny equality of rights under the law." the statute's equal protection language as requiring more than merely an injury that is "not equal." They noted that the plaintiffs' claim failed to allege a discriminatory conspiracy involving "some manipulation of the law or its agencies." 93 Because the Court thought the plaintiffs could seek an adequate remedy under state law, their "rights under the laws and to protection of the laws" remained unimpaired by the conspiracy.94

Collins has generally been understood as holding that state action is a necessary element of the section 1985(c) cause of action..$^{95}$ Indeed, the three dissenters read the holding of the case this way, arguing in response that the "language of the statute refutes the suggestion that action under color of state law is a necessary ingredient of the cause of action which it recognizes" ${ }^{96}$ and defending its constitutionality as so construed. The majority briefly addressed in dictum the constitutional question whether the fourteenth amendment could reach private conduct, ${ }^{97}$ and admitted that its statutory

\footnotetext{
Id. at 661 .

s7 Id.

s8 183 F.2d 308 (9th Cir. 1950), rev'g 80 F. Supp. 501 (S.D. Cal. 1948).

89 Love v. Chandler, 124 F.2d 785 (8th Cir. 1942).

30341 U.S. at 656.

"Id. at 662 .

${ }^{92}$ Id. See id. at 660.

${ }^{93} \mathrm{Id}$. at 661

"Id. at $661,662$.

${ }^{95}$ For example, in the Fifth Circuit decision in Griffin v. Breckenridge, 410 F.2d 817 (5th Cir. 1969), rev'd, 403 U.S. 88 (1971), Judge Goldberg said: "In Collins v. Hardyman, . . . the court held that $\$ 1985(3)$ reached only conspiracies under color of law." Id. at 882.

96 341 U.S. at 663 (Burton, J., joined by Black \& Douglas, JJ., dissenting).

${ }^{27}$ Id. at 658 (majority opinion).
} 
construction was reached partially in order to avoid "constitutional problems of the first magnitude." "98 But they stated neither a constitutional nor a statutory state action requirement. That the Collins majority stopped short of prescribing such a requirement is evident from the Court's dictum: "We do not say that no conspiracy by private individuals could be of such magnitude and effect as to work a deprivation of equal protection of the laws, or of equal privileges and immunities under the laws." "99 The holding seems no broader than that the alleged conspiracy did not involve the type of private conduct within the purview of the statute. ${ }^{100}$ This conclusion accords with the legislative history of the $\mathrm{Ku}$ Klux Klan Act.

\section{B. Griffin v. Breckinridge}

In Griffin v. Breckinridge ${ }^{101}$ the Court had occasion to discuss both Harris and Collins in addressing the scope and constitutionality of section 1985 (c). ${ }^{102}$ The complaint in Griffin stated a scenario typical of the $\mathrm{Ku}$ Klux Klan at its worst. The plaintiffs were black men who had been travelling in Mississippi on state and federal highways. The defendants, white men who mistook the driver of the car for a civil rights worker, blocked the plaintiffs' way, forced them from the car, and beat them with clubs. The Fifth Circuit, on the basis of its reading of Collins as requiring state action, reluctantly concluded that the plaintiffs had not stated a cause of action under section 1985(c). ${ }^{103}$ The Supreme Court reversed.

The Griffin Court's analysis proceeded from its conclusion that Collins "in effect" construed section 1985(c) as reaching only conspiracies under color of state law, ${ }^{104}$ a conclusion the Court found necessary to refute. To support its rejection of the perceived holding of Collins, the Court relied on the text of the statute, its legislative history, and the Court's construction of analogous statutory provisions. The language of the statute itself presents little basis for

9. Id. at 659.

" Id. at 662 (citing the Ku Klux Klan as a possible historical example of such a conspiracy). It is interesting to note that the Collins Court's assessment of the purposes of the Klan was in accord with the 1871 congressional view. The illegal purpose of the Klan was not to be found in private discrimination, or even in private lawlessness, but rather in private attempts to "dominate and set at naught the . . . governments of the day." Id. See text and notes at notes $29-41$ supra.

100341 U.S. at 662.

iII 403 U.S. 88 (1971).

102 See text and notes at notes 16-28 supra.

163410 F.2d 817, 826-27 (5th Cir. 1969), rev'd, 403 U.S. 88 (1971). See text and note at note 15 supra.

14403 U.S. at 92. 
finding a state action requirement, and the Court did not strain to find one. ${ }^{105}$ Citing Harris, the Court noted that there is "nothing inherent" in the statute's proscription of deprivations of equal protection to require that the state be the source of the deprivation. ${ }^{106}$ Similarly, from the legislative history the Court could detect "no suggestion whatever" that the statute should not cover private conspiracies, so long as they are aimed at denying citizens' enjoyment of equality of the rights of citizenship. ${ }^{107}$

The Court's opinion relied heavily on judicial construction of two criminal analogues to section 1985 (c) and on the related civil provisions of the $\mathrm{Ku}$ Klux Klan Act. Focusing on its earliest occasion to consider section 2 of the Act, the Court quoted Harris's construction of the criminal counterpart to section 1985(c): "[T] statute was 'not limited to take effect only in case of [state action],' .. . but 'was framed to protect from invasion by private persons, the equal privileges and immunities under the laws, of all persons and classes of persons. . . " "108 Second, the Court noted that 18 U.S.C. \& $241^{109}$ - "the closest remaining criminal analogue to $\S 1985(3)$ "'110_had been construed to reach private action by individuals other than state officials. ${ }^{111}$ The Court's reliance on these analogous criminal provisions to refute the suggestion of a state action requirement should not be misinterpreted. Indeed, the Court's conclusion that section 1985(c) does not reach "all tortious, conspiratorial, interferences with the rights of others" 112 implies that Harris's questionably broad interpretation of section 2 of the Act of 1871 is not authoritative with respect to section $1985(\mathrm{c}) \cdot{ }^{113}$ Nor should section 241 , which has its own distinct legislative history, be

\footnotetext{
${ }^{105} I d$. at 96.

106 Id. at 97 (citing United States v. Harris, 106 U.S. 629 (1882)).

107 Id. at 100.

${ }^{108}$ Id. at $97-98$.
}

${ }^{109}$ Section 241, derived from the Enforcement Act of 1870, see note 6 supra, provides:

If two or more persons conspire to injure, oppress, threaten, or intimidate any citizen in the free exercise or enjoyment of any right or privilege secured to him by the Constitution or laws of the United States, or because of his having so exercised the same; . . . They shall be fined not more than $\$ 5,000$ or imprisoned not more than ten years, or both.

110403 U.S. at 98 .

i1' See United States v. Williams, 341 U.S. 70 (1951).

112403 U.S. at 101.

${ }^{113}$ The revival by the Griffin Court of Harris's construction of the statute, see 403 U.S. at 97-98, was restricted to the conclusion that section 1985 (c) has no state action requirement. It should not be considered to be a reaffirmation of the 1876 case in all its particulars. But see McLellan v. Mississippi Power \& Light Co., 545 F.2d 919, 925 \& n.21 (5th Cir. 1977) (en banc). 
regarded as dispositive of the scope of section 1985 (c)..$^{114}$

To confirm its conclusion, the Court considered the three forms that a state action limitation might take: "that there must be action under color of state law, that there must be interference with or influence upon state authorities, or that there must be a private conspiracy so massive and effective that it supplants those authorities and thus satisfies the state action requirement." 115 The Court denied that section 1985 (c) was limited in any of these ways. ${ }^{116}$ Because each of the three forms of a state action requirement were found in other parts of the original Act-action under color of state law in section 1 (now section 1983), ${ }^{117}$ direct interference with state authorities in other parts of section 2 (now sections 1985(1) and (2)), ${ }^{118}$ and massive conspiracy in sections 3 and 4 -the Court reasoned that the general clause would be rendered redundant if it too had a state action requirement. ${ }^{119}$

The Court's decision that the acts alleged in Griffin stated a section 1985(c) cause of action accords with the original purpose of the statute. The defendants in Griffin assaulted the plaintiffs on the

II Section 241 embodies the radical Republican view of the fourteenth amendment's enforcement clause: it prohibits private persons from interfering with other persons' exercise or enjoyment of rights secured by the Constitution or federal law. See text and notes at notes 47-53 supra. For example, in United States v. Guest, 383 U.S. 745 (1966), the victim's right to equal use of public facilities was infringed by racist hooligans who murdered him. Six Justices were willing to find this a violation of section 241 , even in the absence of any state involvement in the conspiracy. Id. at 762. Whatever the constitutional merits of this reading under modern theories, see Note, Federal Power to Regulate Private Discrimination: The Revival of the Enforcement Clauses of the Reconstruction Era Amendments, 74 Couum. L. REv. 449, 511-17 (1974), it cannot be doubted that the language of section 241 invites the reading. Moreover, the legislative history of section 241 is devoid of the careful constitutional consideration given to section 1985 (c). The primary speech concerning the provision that is now section 241 manifested a much broader interpretation of the fourteenth amendment than that insisted upon by the moderates in the 1871 debates. See Cong. GroBe, 41st Cong., 2d Sess. 3611-3613 (1870). Where section 1985(c) was limited by amendment to violations of equal rights by direct or indirect frustration of governmental protection, section 241 was not so limited; if the Constitution permits, section 241 may be applied to mere private interference with the enjoyment of federal rights.

i1s 403 U.S. at 98.

116 This is not to say, however, that state action is never a necessary element of a 1985(c) action. If the plaintiff alleges that he had been deprived of a right that is assertable only against the state, then state action must be alleged. See Cohen v. Illinois Inst. of Technology, 524 F.2d 818, 829 n.31 (7th Cir. 1975) (Stevens, J.); Reiss, Requiem for an "Independent Remedy": The Civil Rights Acts of 1866 and 1871 as Remedies for Employment Discrimination, 50 S. CaL. L. REv, 961, 1006-09 (1977).

it 42 U.S.C. $\S 1983$ (1976).

11842 U.S.C. $\$ \$ 1985$ (a) \& (b) (1976).

119 "Given the existence of these three provisions, it is almost impossible to believe that Congress intended, in the dissimilar language of the portion of $\S 1985(3)$ now before us, simply to duplicate the coverage of one or more of them." 403 U.S. at 99. 
highway on the mistaken impression that the driver was a civil rights worker. ${ }^{120}$ There was no hint of state action in any of the three possible forms: no state officers were involved by action or inaction, no state authorities were coerced, influenced, or impeded in the performance of their duty toward the plaintiffs, and.no conspiracy existed so massive as to supplant state authority. Nevertheless, the purpose of the defendants was in part to drive civil rights workers from the state, and thereby to make it less likely politically that the state would carry out its duty of equal protection to blacks. This purpose falls squarely within the scope of conspiratorial designs that prompted the Forty-Second Congress to pass the Ku Klux Klan Act. ${ }^{121}$

Although the holding of Griffin comports with the statute's original meaning, it might be suggested that the spirit of Griffin discourages adoption of an interpretation of the statute that would restrict it to that original meaning. The Court noted, with apparent approval, that "[ $\mathrm{t}] \mathrm{he}$ approach of this Court to other Reconstruction civil rights statutes in the years since Collins has been to 'accord [them] a sweep as broad as [their] language.' "122 It does not follow, however, that language specifically selected by Congress to achieve a limitation on the scope of a statute should be stretched so as to deny the words their intended effect. The Court's holding does not suggest that conspiracies of a wholly different purpose and effect from those motivating the framers of the statute-for example, private acts of discrimination in employment ${ }^{123}$-are also within

120 Id. at 90.

${ }^{121}$ See Part II supra.

122403 U.S. at 97 (quoting Jones v. Alfred H. Mayer Co., 392 U.S. 409, 437 (1968)).

123 See Novotny v. Great Am. Fed. Sav. \& Loan Ass'n, 584 F.2d 1235 (3d Cir. 1978) (en banc) rev'd, 47 U.S.L.W. 4681 (U.S. June 12, 1979).

The Supreme Court, in reversing the Third Circuit's decision in Novotny, indicated that, in order to preserve the "[u]nimpaired effectiveness" of Title VII, it was necessary to hold that "deprivation of a right created by Title VII cannot be the basis for a cause of action under $§ 1985$ (c)." 47 U.S.L.W. at 4684. Justice Stewart's majority opinion noted that section 1985(c) creates no substantive rights and that the right created by Title VII for which plaintiff sought vindication-freedom from gender-based discrimination in employment-did not exist at all prior to enactment of Title VII. Id. Justice Stewart did not, however, address the broader question whether section 1985(c) can ever be invoked to remedy statutory rights.

Concurrences by Justice Powell, id. at 4684 , and Justice Stevens, id. at 4685 , did address this question. Justice Powell stated that, in his view, section 1985(c) "was intended to provide a remedy only for conspiracies to violate fundamental rights derived from the Constitution." id. at 4685 n.* (Powell, J., concurring). Justice Stevens, like Justice Powell, concluded that section 1985(c) was not intended to provide a remedy "for the violation of statutory rights." Id. at 4686 (Stevens, J., concurring). Justice Stevens stated that section 1985(c) provides a remedy for rights "protected by the Constitution and, in particular, the newly ratified Fourteenth Amendment." Id. at 4685 (Stevens, J., concurring). With respect to fourteenth 
the statute's reach. The Griffin Court insisted as much by expressly recognizing the necessity of "giving full effect to the congressional purpose" by restricting the scope of the action in the manner intended by the sponsors of the "limiting amendment." 124 In order to decide the Griffin case, it was not necessary to explore the full extent of the limiting amendment- the requirement of discriminatory animus sufficed for Griffin's purposes ${ }^{125}$-but the opinion endorses, in principle, the restriction of section 1985(c) in accordance with its extensive legislative history. ${ }^{126}$

\section{Reasons for Following the Original Meaning of the Statute}

The Ku Klux Klan crisis of the postbellum South is over; present-day plaintiffs, no longer concerned that states are unable or unwilling to provide equal protection of the laws, seek a federal forum under section 1985(c) for quite different reasons. Some courts and commentators have responded by misinterpreting the Ku Klux Klan Act as a general antidiscrimination statute, applying it broadly for the redress of inequality. ${ }^{127}$ Novotny $v$. Great American

amendment rights, Justice Stevens emphasized that an actionable conspiracy must prevent or hinder state authorities from providing equal protection of the laws. Id. at 4686 (Stevens, J., concurring).

124403 U.S. at 102. See id. at 101-02.

125 Griffin, the Court said, presented a violation "so close to the core of the coverage intended by Congress that it is hard to conceive of wholly private conduct that would come within the statute if this does not." Id. at 103. Apparently, the Court intended to leave further limitation on the cause of action to cases less close to the Ku Klux Klan paradigm.

123 See McLellan v. Mississippi Power \& Light Co., 545 F.2d 919, 924, 925 (5th Cir. 1977) (en banc), which noted that the Griffin Court did not intend its "racial, or otherwise classbased animus" language to constitute the only restriction on the second element of the cause of action. The court concluded: "To satisfy Griffin's second requirement there must be both the private deprivation of the enjoyment of the laws and a class-based, discriminatory motivation. Together, the two amount to a private denial of the equal protection of the laws." Id. at 924 .

Recently, in dictum, the Court stated that " 2 of the 1871 Act as passed, unlike $\S 1$, prosecuted persons who violated federal rights whether or not that violation was under color of official authority, apparently on the theory that Ku Klux Klan violence was infringing the right of protection defined by Coryell." Monell v. New York City Dep't of Social Servs., 436 U.S. 658, $670 \mathrm{n} .21$ (1978). Presumably, the Court did not intend in this footnote to undermine its holding in Griffin that not all violations of federal rights are governed by section 1985(c). Apparently the Monell Court mistook the position of the Radical Republicans for that of the 1871 Congress. Corfield v. Coryell, 6 F. Cas. 546 (No. 3230) (C.C.E.D. Pa. 1823), moreover, concerned "privileges and immunities" of state citizenship, not, as the Monell Court implied, "the right of protection." Finally, Congress sought to suppress the Klan not because individuals were deprived of life or property, but because the constitutional authorities were hindered in the performance of their equal protection obligations. See text and notes at notes 68-74 supra. The Monell footnote should not be regarded as an authoritative pronouncement on the meaning of section 1985 (c).

I7 See, for example, the cases collected in note 3 supra; Reiss supra note 116; Note, supra 
Federal Savings \& Loan Association ${ }^{128}$ is perhaps the best example of this interpretation. The en banc opinion, written by Judge Adams for a unanimous Third Circuit, described the Ku Klux Klan Act as "couched in expansively drafted legislation." ${ }^{129}$ Although the court recognized that "[n]arrowly construed," the Act might not support the plaintiff's cause of action, ${ }^{130}$ it reasoned that "the statutory landscape is illuminated by the community's goals as well as the emanations of legislative history. To hobble the legislation before us would without justification, set judicial authority against the effort to achieve equality of rights." 131

That the enacting Congress did not intend courts to engage in such a free-wheeling, egalitarian inquisition is evident from the legislative history; ${ }^{132}$ that the Supreme Court has not endorsed such a reading of the statute is equally clear. The Griffin Court emphasized that the conduct there involved lay "so close to the core of the coverage intended by Congress that it is hard to conceive of wholly private conduct that would come within the statute if this does not." 133 The Court, eschewing a broadly expansive reading of the statute, chose instead to give "full effect" to the purpose of the limiting amendment. ${ }^{134}$ The Griffin Court's concerns about interpreting section 1985(c) as a general federal tort law have proved well founded: some judges have taken section 1985(c) well beyond "tortious, conspiratorial interferences with the rights of others" to interferences with statutory and other rights quite far from the core of the coverage intended by Congress. ${ }^{135}$ It is important to remember

note 114, at 495-500; Note, Section 1985(3): A Viable Alternative to Title VI for Sex-based Employment Discrimination, 1978 WASH. U.L.Q. 367.

${ }^{123} 584$ F.2d 1235 (3d Cir. 1978) (en banc), rev'd, 47 U.S.L.W. 4681 (U.S. June 12, 1979).

See Ackley v. Maple Woodman Assocs., 47 U.S.L.W. 2647 (Ohio C.P.Ct. Mar. 21, 1979).

120584 F.2d at 1261.

${ }^{130}$ Id.

is Id. at 1261-62. But see McLellan v. Mississippi Power \& Light Co., 545 F.2d 919 (5th

Cir. 1977) (en banc).

132 See Part II supra.

${ }^{133}, 403$ U.S. at 103.

134 Id. at 102.

${ }^{135}$ In some cases the courts have viewed section 1985(c) as a remedy for violations of statutory rights. See, e.g., Novotny v. Great Am. Fed. Sav. \& Loan Ass'n, 584 F.2d 1235 (3d Cir. 1978) (en banc), rev'd, 47 U.S.L.W. 4681 (U.S. June 12, 1979); Hodgin v. Jefferson, 447 F. Supp. 804 (D. Md. 1978); Local No. 1 (ACA), Broadcast Employees v. International Bhd. of Teamsters, 419 F. Supp. 263 (E.D. Pa. 1976); Milner v. National School of Health Technology, 409 F. Supp. 1389 (E.D. Pa. 1976). Others have not depended on such a statutory basis. See, e.g., Bethel v. Jendoco Constr. Corp., 570 F.2d 1168 (3d Cir. 1978) (right to be free from racial discrimination by private employers); Coley v. M \& M Mars, Inc., 461 F. Supp. 1073 (M.D. Ga. 1978) (right of black female plaintiff to be free from discriminatory harassment by fellow employees); Marchwinski v. Oliver Tyrone Corp., 461 F. Supp. 160 (W.D. Pa. 1978) 
that it is a statute, not a constitution, that we are interpreting. ${ }^{136}$ Although the words of the statute need not be frozen rigidly in the meanings originally ascribed to them by their draftsmen, they should not be assumed to be infinitely elastic.

\section{A. Considerations of Federalism}

At the heart of the Griffin Court's fear of overextending section 1985(c) was the prospect of federalizing tort law ${ }^{137}$ - a fear equally applicable to section 1985(c) actions based on contractual or other rights grounded in state law. ${ }^{138}$ In this the Court echoed the constitutional and prudential concerns of the 1871 Congress, which sought to preserve the traditional balance of state and federal authority. ${ }^{139}$ One might argue, as did the radical Republicans whose efforts were stymied by the moderate majority in 1871 , for centralized federal power governing rights based on tort, contract, property, or state statute; ${ }^{140}$ the fundamental constitutional decision made by the Founders in 1787 and reaffirmed by the Congresses in the years following the Civil War was otherwise. ${ }^{141}$

(right to be free from gender-based discrimination by private employers); South Cutler Bay, Inc. v. Metropolitan Dade County, 349 F. Supp. 1205 (S.D. Fla. 1972) (property rights); Cordeco Dev. Corp. v. Valesquez, 354 F. Supp. 1355 (D.P.R. 1972) (property rights); Ackley v. Maple Woodman Ass'n, 47 U.S.L.W. 2647 (Ohio C.P. Ct. Mar. 21, 1979) (right to enforce rights granted to tenants under the Ohio landlord-tenant law).

The Court's recent decision in Great Am. Fed. Sav. \& Loan Ass'n v. Novotny, 47 U.S.L.W. 4681 (U.S. June 12, 1979), see note 123 supra, will not necessarily forestall the tendency of the lower courts to apply section 1985(c) expansively. The Court decided only the narrow question whether section 1985(c) can be invoked to remedy Title VII violations. Id. at 4684; see id. at $4685 \mathrm{n} .{ }^{*}$ (Powell, J., concurring) ("The doubts which will remain after the Court's decision are far from insubstantial.") (citing cases applying section 1985(c) to statutory rights other than Title VII).

136 Cf. Bickel, The Original Understanding and the Segregation Decision, 69 Harv. L. Rev. 1, 59 (1955) ("If the fourteenth amendment were a statute, a court might very well hold, on the basis of what has been said so far, that it was foreclosed from applying it to segregation in public schools. . . . But we are dealing with a constitutional amendment, not a statute.")

137403 U.S. at 102.

138 McLellan v. Mississippi Power \& Light Co., 545 F.2d 919, 931 n.67 (5th Cir. 1977) (en banc).

135 See, e.g., CoNG. GLOBE, supra note 31, app., at 187, col. 3 ("in the minds of those who framed the Constitution probably no belief was firmer than that for all time it was much safer to leave the States to protect the rights of the people than to place that duty upon the General Government. I believe that in this they were especially wise.") (remarks of Congressman Williard (R-Vt.)). See also Note, supra note 7, at 1156.

140 Congressman Hoar of Massachusetts, one of the supporters of the original version of section 2, argued on policy grounds for the centralization of power in the federal government, claiming that a majority in a state is much more likely to support oppressive measures than a majority of the entire nation. CoNG. GLOBE, supra note 31, at 334, col. 3, to 335, col. 1 .

111 The policies that inspired that original constitutional decision-the dangers of a distant, centralized national authority unmediated by the intervening powers of the 
The method employed by the Griffin Court to avoid upsetting the federal-state balance-the "discriminatory animus" requirement-has not proven sufficient to achieve its purpose. Unless the limiting language in Griffin is interpreted to restrict section 1985(c) coverage beyond the animus requirement specifically prescribed in that opinion, a federal tort law will grow to reach conspiracies motivated by race, ${ }^{142}$ gender, nationality, handicap, age, religion, wealth, opinion, or any other class characteristic-limited only by the commerce clause and other relevant constitutional provisions. Moreover, the federalization will proceed beyond the tort law to other areas constitutionally entrusted to the states.

Some courts have attempted to staunch the flow of section 1985 (c) litigation by a variety of strategems, ${ }^{143}$ apparently believing that miscellaneous restrictions on the cause of action are to be preferred to a straightforward interpretation along the lines envisioned by the enacting Congress. An especially valiant effort was made by Judge Godbold, dissenting in McLellan v. Mississippi Power \& Light Co. ${ }^{144} \mathrm{He}$ claimed that the "fear" of federalizing tort law was "unnecessary," 145 and cited several limitations on the 1985(c) cause of action that might keep the statute within sensible bounds. ${ }^{146}$

Judge Godbold suggested that the class-based animus requirement could control the number of potential plaintiffs under section 1985(c), ${ }^{147}$ since plaintiffs discriminated against as individuals rather than as members of a class would be screened out of the statute's coverage. Moreover, he would limit the coverage of the statute to certain classes. It might be sufficient to answer this latter

states-need not be rehearsed here. See generally R. Goldwin, A Nation of Statrs: Essays on the American Federal System (1961); A. DE Tocqueville, Democracy in America 87-98, 115-20, 155-70, 262-63, 363-95, 674-89 (Anchor Books ed. 1969); Corwin, The Passing of Dual Federalism, 36 VA. L. Rev. 1 (1950); Diamond, The Federalists's View of Federalism, in Essays in Federalism (G. Benson ed. 1961); Redfield, The Proper Limits Between State and National Legislation and Jurisdiction, 15 AM. L. REG. 193 (1867).

${ }^{142}$ See The Supreme Court, 1970 Term, 85 Harv. L. REv. 40, 99 (1971).

14 One state court has described this process as a "course of sophistry that would warm the cockles of the heart of a 14th century metaphysicist." Ackley v. Maple Woodman Assoc., 47 U.S.L.W. 2647 (Ohio C.P. Ct. Mar. 21, 1979).

14 545 F.2d 919, 934-41 (5th Cir. 1977) (Godbold, J., joined by Brown, C.J. \& Goldberg, J., dissenting).

145 Id. at 940 .

${ }^{116}$ In addition to those points discussed in the text infra, Judge Godbold mentioned, without endorsing, a construction of "conspiracy" that would not include concerted action of a corporation and its agents. Id. (citing Dombrowski v. Dowling, 459 F.2d 190 (7th Cir. 1972) (holding that a corporation cannot conspire with itself for purposes of section 1985(c))). See note 27 supra.

147545 F.2d at 940-41 (Godbold, J., dissenting). 
suggestion by noting that Judge Godbold would include bankrupts within the list of classes protected by the statute. ${ }^{148} \mathrm{~A}$ further objection to this proposed limitation is that, in light of the legislative history, the class-based animus requirement is legitimately susceptible to broad interpretation. That protected classes are not limited to those with immutable characteristics is evident from Congress's concern with protecting Republicans; ${ }^{140}$ that they are not limited to stigmatized classes is evident from statements in the legislative history that Democrats, Methodists, and even Vermonters would receive protection. ${ }^{150}$

Judge Godbold also noted that the requisite discrimination must be "invidious," by which he seemed to mean unreasonable or unjustified.151 For instance, he said that "legitimate commercial practices" would not give rise to liability. ${ }^{152}$ So far as this requirement places on the defendant the often difficult burden of justifying his conduct, it provides little reliable protection ${ }^{153}$-nor does it restrict federal control over the challenged conduct. It offers merely an affirmative defense, not a limitation on the action itself. Indeed, the judge's separate point that the defendant retains affirmative defenses to the section 1985(c) suit-for example, official immunity ${ }^{154}$-is not a significant limitation. The eroding doctrine of official immunity is an unreliable protection. ${ }^{155}$ Moreover, this suggestion is subject to the same objection as the last. It does not preserve

14s Id. at 939-40.

'1' Several courts have attempted to limit the classes protected by section 1985 (c) to groups based on "immutable characteristics," despite the evidence that the principal protected group in the eyes of the enacting Congress was Republicans. See Carchman v. Korman Corp., 594 F.2d 354, 355 (3d Cir. 1979); Novotny v. Great Am. Fed. Sav. \& Loan Ass'n, 584 F.2d 1235,1243 (3d Cir. 1978) (en banc), rev'd, 47 U.S.L.W. 4681 (U.S. June 12, 1979); Murphy v. Mt. Carmel High School, 543 F.2d 1189, 1192 n.1 (7th Cir. 1976); Harrison v. Brooks, 519 F.2d 1358, 1359-60 (1st Cir. 1975); Arnold v. Tiffany, 359 F. Supp. 1034, 1036 (C.D. Cal.), aff'd on other grounds, 487 F.2d 216 (9th Cir. 1973), cert. denied, 415 U.S. 984 (1974); cf. Bellamy v. Mason's Stores, Inc., 508 F.2d 504 (4th Cir. 1974) (leaving unanswered whether Klan members are a protected class under the Act). But see Cameron v. Brock, 473 F.2d 608 (6th Cir. 1973); Azar v. Conley, 456 F.2d 1382 (6th Cir. 1972); Action v. Gannon, 450 F.2d 1227 (8th Cir. 1971); Ackley v. Maple Woodman Assocs., 47 U.S.L.W. 2647 (Ohio C.P. Ct. Mar. 21, 1979). See generally Note, supra note 12, at 252-56.

150 Cong. GLoBE, supra note 31, at 567, col. 2 (remarks of Sen. Edmunds (R.-Vt.)).

151545 F.2d at 941 (Godbold, J., dissenting).

152 Id.

133 Cf. Note, Developments in the Law-Employment Discrimination and Title VII of the Civil Rights Act of 1964, 84 HaRv. L. REv. 1109, 112d23 (1971) (describing the difficulties of establishing the job-relatedness of employment tests).

1s 545 F.2d at 941 (Godbold, J., dissenting).

is See, e.g., Butz v. Economou, 438 U.S. 478 (federal executive officials not absolutely immune from damage suits). 
state control over the action; it merely affects the outcome of some cases.

Finally, Judge Godbold mentioned that constitutional limitations on the power of Congress might limit the statute's scope. ${ }^{156}$ This limitation will be especially potent when the rights allegedly deprived are secured only against interference by the state or the federal government. Where the defendant's actions affect interstate commerce, injure black persons, or infringe rights of national citizenship, however, this constitutional limitation limits not at all. ${ }^{157}$

Judge Godbold is, of course, correct that the limitations he cites will enable fewer plaintiffs to prevail, but these limitations do not constitute a significant barrier to unwarranted expansion of federal authority. For that, it is necessary to return to Griffin's suggestion: to give "full effect" to the purpose of the limiting amendment. ${ }^{158}$ The amendment was precisely designed to confine section 1985(c) to the reach authorized by the fourteenth amendment. ${ }^{159}$ Tort, contract, property, and other state law would be undisturbed: the federal power would be exerted only against private conspirators whose intention is to affect or prevent the state's provision of equal protection of the laws. This result would also accord with-indeed, may be mandated by-the principle of statutory construction that an act of Congress is deemed to have left the federal-state balance unaffected unless the contrary is clearly indicated. ${ }^{160}$

\section{B. Disruption of Related Statutory Schemes}

A second policy reason for adopting the original meaning of section 1985(c) is to prevent disruption of related statutory schemes, especially in the area of civil rights. Section 1985(c), if applied by the courts in a manner uninformed by its legislative history, could

is 545 F.2d at 941 (Godbold, J., dissenting).

137 Adoption of the expansive readings of the fourteenth amendment's enforcement clause found in the concurrences of Justices Clark and Brennan in United States v. Guest, 383 U.S. 745, 762, 782 (1966), would effectively strip section 1985(c) of any constitutional restriction. See generally Cox, Foreword: Constitutional Adjudication and the Promotion of Human Rights, 80 HaRv. L. REv. 91, 108-21 (1966).

158403 U.S. at 102.

139 See text and notes at notes 65-74 supra.

160 Justice Marshall has stated the principle as follows:

Unless Congress conveys its purpose clearly, it will not be deemed to have significantly changed the federal-state balance . . . . In traditionally sensitive areas, such as legislation affecting the federal balance, the requirement of clear statement assures that the legislature has in fact faced, and intended to bring into issue, the critical matters involved in the judicial decision.

United States v. Bass, 404 U.S. 336, 349 (1971). See also United States v. Enmons, 410 U.S. 396, 411-12 (1973); Rewis v. United States, 401 U.S. 808, 812-13 (1971). 
be read to provide a civil remedy for infringement of any rights granted by statute, regulation, or administrative order. Moreover, where a plaintiff's cause of action is based upon rights created by another statute, the remedy under section 1985(c) need not be limited to the procedural and remedial provisions of the substantive act.

For example, an employee discharged because of his race may sue under Title VII ${ }^{161}$ for reinstatement and back pay, provided he complies with certain procedural prerequisites. ${ }^{162} \mathrm{By}$ suing under section 1985(c), claiming infringement of his Title VII rights, the plaintiff might be able to avoid the procedural limitations of Title VII and to obtain punitive and compensatory relief greater than that provided therein. ${ }^{163}$ It might be thought that in deriving the substantive right from Title VII, the plaintiff would be relegated to that Act's procedures and remedies: section 1985(c) would not seem to add anything to the plaintiff's case. No court has yet sustained a 1985(c) action based on an independent statutory right where the plaintiff failed to comply with the procedures mandated by the substantive act. ${ }^{164}$ But this does not seem to be an unlikely prospect in light of United States $v$. Johnson, ${ }^{165}$ in which the Court in an analogous situation stripped a substantive standard of its limitations on relief by permitting prosecution under a general remedial civil rights statute.

The defendants in Johnson were indicted under 18 U.S.C. $\S$ $241 .{ }^{166}$ They had attacked black patrons of a restaurant, in violation of their right to equality in public accomodations under Title II of the Civil Rights Act of 1964. ${ }^{167}$ The Supreme Court upheld the indictment under section 241, even though Title II provides only for injunctive relief and states explicitly: "The remedies provided in this title shall be the exclusive means of enforcing the rights based

16142 U.S.C. $\$ 2000 \mathrm{e}$ (1976). See generally Note, supra note 153.

162 See Winslow, Sex Discrimination in Employment: Current Federal Practices, 24 Drake L. Rev. 515, 539-58 (1975); Note, supra note 153, at 1199-1216.

its See Note, supra note 127.

16" See, e.g., Novotny v. Great Am. Fed. Sav. \& Loan Ass'n, 584 F.2d 1235 (3d Cir. 1978) (en banc), rev'd, 47 U.S.L.W. 4681 (U.S. June 12, 1979) (plaintiff satisfied procedural prerequisites of Title VII). Although the Supreme Court's Novotny decision, see notes 123, 125 supra, explicitly foreclosed this possibility for suits based on Title VII, it is not clear that the Court would reach the same conclusion with respecf to statutory procedural requirements that are not so essential to a statute's "balance, completeness, and structural integrity." See Novotny, 47 U.S.L.W. at 4684 (quoting Brown v. General Serv. Admin., 425 U.S. 820, 832 (1976)).

16s 390 U.S. 563 (1968).

16 18 U.S.C. $\$ 241$ (1976).

In 42 U.S.C. $\$ 2000 \mathrm{a}$ (1976). 
on this title." ${ }^{168}$ The congressional decision to provide only injunctive relief arose from a concern that the coverage of the Title was unclear and that defendants should be able to defend the legality of their actions in the civil suit prior to being subjected to criminal sanctions. ${ }^{169}$ The Johnson decision upset that congressional judgment.

Johnson cannot be distinguished from the application of section 1985(c) to Title VII rights. Indeed, Johnson presented a weaker case for employing a general civil rights statute to enforce a specific statutory right. First, Title II was explicitly declared the exclusive remedy for rights created under it, while Title VII contains to such statement. ${ }^{170}$ Second, the decision in Johnson to apply criminal sanctions where only injunctive relief was provided by Congress is a much more extreme expansion of remedies than enlarging the damage action provided in Title VII by permitting suit under section 1985(c).

If section 1985(c) is read expansively to reach conspiracies to violate antidiscrimination statutes, the doctrine of Johnson could prevent the restrictions on remedies in those statutes from being incorporated in the 1985(c) action. By analogy, courts could be expected to find procedural limitations-such as statutes of limitations, exhaustion requirements, or other prerequisites to suit-inapplicable to suits filed under section 1985(c). By interpreting section 1985(c) as unfettered by the procedural and remedial limitations of related statutes, the congressionally mandated limitations of a large number of statutes could be avoided. ${ }^{171}$ For example, Title IX of the Educational Amendments of $1972^{172}$ provides exclusively administrative remedies for gender-based discrimination in

${ }^{168} I d . \S 2000 \mathrm{a}-6(\mathrm{~b})$. The statute also provides that "nothing in this title shall preclude any individual or any State or local agency from asserting any right based on any other Federal or State law not inconsistent with this title." Id. Although this proviso may have influenced the Court, 390 U.S. at 566, it should not have affected the disposition of the case. First, the reservation of the rights of states or local agencies to pursue other remedies cannot support a federal prosecution. Second, the rights infringed in Johnson were not "based on any other Federal or State Law." They were based on Title II; section 241 was merely a vehicle for enforcing them.

its See 390 U.S. at 564-65.

170 Alexander v. Gardner-Denver Co., 415 U.S. 36, 47, 48 \& n.9, 49 (1974).

17 See note 135 supra. Of course, in many instances it is proper for courts to imply causes of action based on statutes that contain no such explicit provision. Rather than use section 1985(c) for this purpose, it is preferable to apply the analysis of Cort v. Ash, 422 U.S. 66, 78 (1975). Implication of a private remedy should thus be confined to instances in which the statute creates a special right in the plaintiffs, the result accords with the legislative history and the statutory purpose, and the action is appropriately governed by federal rather than state law. Use of section 1985(c) goes far beyond these limitations.

17220 U.S.C. $\S \S 1681-1686(1976)$. 
educational programs, but section 1985(c) might be used to create an action for damages. Similarly, the Rehabilitation Act of $1973^{173}$ and the Age Discrimination in Employment Act ${ }^{174}$ would provide damage actions for the handicapped and the aged, though Congress provided no such remedy. Presumably, even executive orders and administrative regulations enforceable by such sanctions as the withholding of government contracts ${ }^{175}$ would be held to provide bases for 1985(c) actions, so long as they are designed to protect persons from class-based injury or discrimination.

To expand section 1985(c) in this manner would be to mock the legislative process. Congress should be permitted to balance the specific purposes of the legislation against the wider interests of the economy or the public, or to prescribe the means of enforcement that it considers the wisest or most efficacious. It might be argued that in the short run, civil rights plaintiffs would benefit from such a course of events; they would be freed from procedural limitations and permitted the widest range of possible remedies. ${ }^{176}$ In many instances, however, the cause of advancing equality will be inhibited, rather than promoted, by this result. In Title VII, for example, Congress has determined that the best means of integrating the workplaces of America is through negotiation between the EEOC and business for the benefit of members of minority groups. ${ }^{177} \mathrm{Dam}$ age actions may frustrate this process. Moreover, in the long run, the ability of the political branches to craft protections in the future may be curtailed by inflexibility in setting procedures and remedies. ${ }^{178}$

\footnotetext{
17329 U.S.C. $\S 794$ (1976). See Exec. Order No. 11914, 3 C.F.R. 117 (1970).

17429 U.S.C. $\$ \S 621-634$ (1976).

175 See, e.g., Exec. Order No. 11246, 3 C.F.R. 401 (1970).

17 See Note, supra note 127.

177 See Burlington N., Inc. v. EEOC, 582 F.2d 1097, 1099-1100 (7th Cir. 1978), cert.
} denied, 99 S. Ct. 1267 (1979); Sears, Roebuck \& Co. v. EEOC, 581 F.2d 941, 942-43 (D.C. Cir. 1978). See Also H. FrendLy, supra note 7, at 84-87.

178 The issue of overlapping civil rights statutes has also arisen in connection with other post-Civil War statutes, especially section 1981, which provides a civil remedy for acts of private discrimination. 42 U.S.C. \$ 1981 (1976); see Note, Is Section 1981 Modified by Title VII of the Civil Rights Act of 1964?, 1970 Duke L.J. 1223; note 7 supra. The Supreme Court has held that plaintiffs may pursue their rights under section 1981 and Title VII independently. Johnson v. REA, Inc., 421 U.S. 454, 459 (1975). In so holding, the Court acknowledged that the section 1981 action might interfere with the conciliatory purposes of Title VII. Id. at 461. The interference caused by section 1981, however, is of a different kind than that of section 1985(c). The former is an independent substantive provision; it carries with it both rights and a remedy. Section 1985 (c), in contrast, merely provides a remedy for rights created elsewhere. To permit a Title VII plaintiff to state his claim under section 1985(c) would be to permit him to take advantage of the liberal aspects of Title VII enforcement without 
These untoward consequences could be avoided by narrowing or rejecting the holding of Johnson; alternatively, it could be avoided by adhering to the original meaning of section 1985 (c). The enacting Congress did not intend the statute to be an antidiscrimination law. The language of equal protection and equal privileges and immunities was added as a limitation, not as an expansion..$^{179}$ The fundamental congressional purpose was to prevent private conspiracies from taking over the government, or from affecting the political environment so as to inhibit state authorities from according equal protection to their citizens. It seems doubtful that the 1871 Congress, had it considered the matter, would have intended the statute to disrupt or promote the antidiscrimination schemes passed by its successors. By following an interpretation of the Act based on the original intent, it is possible to avoid such disruption.

\section{Conclusion: Contemporary Cases and the Original Meaning}

This comment has suggested that the original purpose of section 2 of the Ku Klux Klan Act was to prevent conspirators from interfering with the willingness or ability of the constituted authorities to provide equal protection of the laws or to secure equal privileges and immunities under the laws. Congress went quite far in prohibiting such activities; the statute reaches even conduct with mere indirect effect upon the authorities, such as terror directed at persons promoting the equality of rights. On the other hand, Congress was not willing, given its constitutional scruples, to punish private individuals for interference with the private rights of others. Although such constitutional concerns may seem less troublesome in light of modern theory, in interpreting the statute it is wise-if not required-to conform to the original meaning.

Perhaps because the statute was but recently revived, resulting in a discontinuity in its development, courts have not been inclined to give full consideration to the original meaning. ${ }^{180}$ Rather, they have proposed a variety of unrelated limiting principles of uncertain origin and effect. To return to the original meaning will require a

\footnotetext{
complying with its procedural restrictions. The congressional decision not to make Title VII an exclusive remedy does not imply that it may be abused in such a fashion.

139 See text and notes at notes 65-74 supra.

${ }^{180}$ Several courts have, however, used portions of the legislative history to support particular conclusions. See, e.g., Griffin v. Breckinridge, 403 U.S. 88, 99-102 (1971); Novotny v. Great Am. Fed. Sav. \& Loan Ass'n, 584 F.2d 1235, 1239, 1241-42, 1244, 1246 n.47, 1247, 1248, 1249-50, 1257 (3d Cir. 1978) (en banc), rev'd, 47 U.S.L.W. 4681 (U.S. June 12, 1979); Alvarez v. Wilson, 431 F. Supp. 136, 141 (N.D. Ill. 1977).
} 
rethinking of some of the facutal situations that have given rise to section 1985(c) litigation.

\section{A. Conspiracies Involving Government Officials}

One broad group of cases left unaffected by the adoption of the original meaning are those involving state or municipal officials as members of the conspiracy. ${ }^{181}$ When state officials are involved, the conspiracy necessarily will affect the ability or willingess of the authorities to accord equal protection of the laws. Cameron $v$. Brock ${ }^{182}$ is illustrative. The defendants in Cameron were a Tennessee sheriff and his political cronies who conspired to arrest the plaintiff, a supporter of the sheriff's electoral opponent. The plaintiff had been distributing a pamphlet containing strongly worded allegations of impropriety in the conduct of the sheriff's office. The Sixth Circuit panel held that the supporters of a political candidate may constitute a class for purposes of section 1985(c) ${ }^{183}$ and affirmed a jury verdict in the plaintiff's favor. ${ }^{184}$ The defendants' conduct plainly fell within the congressional purpose of preventing conspiracies to interfere with the provision of equal protection by the state; indeed, the instance is not much different from certain Klan outrages recounted in the legislative history. In cases such as Cameron, involving state officials as conspirators, the statute is little different from section 1983. 185

Section 1985(c) might appear to operate in the same fashion when the conspirators include a federal officer. ${ }^{186}$ An argument can be made that the section would make a significant contribution to the array of civil rights remedies, because section 1983 does not apply to federal officials. Although the Court has established that the fifth amendment includes a substantive right to equal treatment

181 See, e.g., Glasson v. City of Louisville, 518 F.2d 899 (6th Cir.), cert. denied, 423 U.S. 930 (1975); Wooldridge v. Virginia, 453 F. Supp. 1333 (E.D. Va. 1978); Curran v. Portland Superintending School Comm., 435 F. Supp. 1063 (D. Me. 1977); Larvadain v. Rapides Parish School Bd., 348 F. Supp. 24 (W.D. La. 1972).

182473 F.2d 608 (6th Cir. 1973).

183 Id. at 610 .

ist Id. at 611 .

iss Where state officials are involved in the conspiracy, the only difference between the application of sections 1983 and 1985 (c) is that the latter is confined to deprivations based on class-based discriminatory animus.

is Some courts have so held. See, e.g., Dry Creek Lodge, Inc. v. United States, 515 F.2d 926, 931 (10th Cir. 1975); Bowers v. Campbell, 505 F.2d 1155 (9th Cir. 1974); Williams v. Wright, 432 F. Supp. 732, 738 (D. Ore. 1976); Revis v. Laird, 391 F. Supp. 1133, 1139 (E.D. Cal. 1975). But see Bethea v. Reid, 445 F.2d 1163, 1165 (3d Cir. 1971); Williams v. Halperin, 360 F. Supp. 163, 165 (D. Colo. 1974). 
by the federal government, ${ }^{187}$ this judicial development was unknown to the legislators who enacted section 1985(c). Thus, a reading of the statute in light of its original meaning would suggest that section 1985(c) provides no remedy for that right. Plaintiffs seeking to redress deprivations of equal protection by federal officials must therefore continue to rely on the peculiar doctrine of Bivens $v$. Six Unknown Named Agents. ${ }^{188}$

\section{B. Private Conspiracies}

1. Deprivations of Federal Statutory Rights. Where the conspirators are private persons, the courts have frequently mistaken the mission of section 1985(c). Its purpose was to ensure the governmental provision of equal protection, not to protect individuals from the tortious acts of others. A clear example of this confusion appears in those cases in which the conspirators allegedly invade private rights secured by federal statute. ${ }^{189}$ Such rights may run against private individuals, rather than states; nevertheless, courts have sometimes regarded their infringement as violating section $1985(\mathrm{c})$, especially when the rights reflect a concern about invidious discrimination. For example, in Local No. 1 (ACA), Broadcast Employees $v$. International Brotherhood of Teamsters, ${ }^{180}$ the court sustained a section 1985(c) claim based on a violation of the labor laws, and in Novotny v. Great American Federal Savings \& Loan Association, ${ }^{191}$ the circuit court sustained a claim based on violation of Title VII. As this comment has sought to demonstrate, the Ku Klux Klan Act was intended to protect the rights of citizens to equal treatment by the government; it does not concern private discrimination or other violations of private rights secured by federal law. ${ }^{192}$

187 Schlesinger v. Ballard, 419 U.S. 498 (1975); Bolling v. Sharpe, 347 U.S. 497 (1954).

188403 U.S. 388 (1971) (implying a cause of action for damages against federal agents under the fourth amendment); cf. Davis v. Passman, 47 U.S.L.W. 4643 (U.S. June 5, 1979) (implying a Bivens cause of action under the fifth amendment); United States Marine Lines, Inc. v. Shultz, 498 F.2d 1146 (4th Cir. 1974) (same).

1s E.g., Hodgin v. Jefferson, 447 F. Supp. 804 (D. Md. 1978) (alleging violation of Equal Pay Act, 29 U.S.C. § 206 (1976)).

190419 F. Supp. 263 (E.D. Pa. 1976).

19584 F.2d 1235 (3d Cir. 1978) (en banc), rev'd, 47 U.S.L.W. 4681 (U.S. June 12, 1979). Novotny might have been able to allege a section 1985(c) cause of action independent of Title VII. He was allegedly discharged from his job because of his persistent efforts to promote fair employment opportunity for women within the company. Id. at 1237-38. His discharge might thus have been viewed as an attempt to stifle an advocate of equal protection, obstructing the state's provision of equal protection to women.

192 This is not to say that Congress has no power to enact and enforce federal antidiscrimination legislation, but that in section 1985(c)-part of the "Act to Enforce the Fourteenth Amendment"- it did not intend to do so. 
Although no court has relied on the original meaning of the statute to reach this conclusion, it has been reached by other routes. ${ }^{193}$

2. Deprivations of Constitutional Rights. Another important example of the courts' departure from the original meaning of the statute appears in cases upholding a section 1985(c) cause of action for private violations of free speech, association, or religion. ${ }^{194}$ In Action v. Gannon, ${ }^{105}$ the Eighth Circuit, en banc, upheld such an action on behalf of parishioners of the Roman Catholic Cathedral in St. Louis, whose services were repeatedly disrupted by militant political groups. In Westberry $v$. Gilman Paper Co., ${ }^{198}$ a panel of the Fifth Circuit upheld such an action on behalf of an environmental activist whose employer's officers and agents allegedly conspired to fire and kill him. A court following the original meaning of section 1985(c) would have dismissed both of these actions.

The Westberry opinion discussed three earlier court of appeals decisions upholding actions based on private conspiracies "aimed at preventing the state from performing its Fourteenth Amendment duties." 197 The court said that these earlier cases differed from the Westberry situation only in "the immediacy of the relationship between the state and the injured person."198 No constitutional distinction could rest on the presence or absence of a "non-injuring state representative," according to the court, "if we are to retain the amendment's focus on protection of the victim." 199 The court therefore concluded that section 1985(c) protects persons from private acts that, if done by a state official, would constitute a first amendment violation..$^{200}$

The Action-Westberry theory is faulty on both constitutional

${ }^{133}$ In Doski v. M. Goldseker Co., 539 F.2d 1326 (4th Cir. 1976), the court rejected a 1985(c) claim based on Title VII, saying that the 1964 Congress intended Title VII "to be the exclusive remedy for effectuating rights created by the statute." Id. at 1334 .

14 See, e.g., Richardson v. Miller, 446 F.2d 1247 (3d Cir. 1971); Pendrell v. Chatham College, 370 F. Supp. 494 (W.D. Pa. 1974). But see Murphy v. Mt. Carmel High School, 543 F.2d 1189 (7th Cir. 1976); Bellamy v. Mason's Stores, Inc. 508 F.2d 504 (4th Cir. 1974); Note, Civil Rights-State Action Is a Requirement for the Application of Section 1985(3) to First Amendment Rights, 54 N.C.L. REv. 677 (1976).

135450 F.2d 1227 (8th Cir. 1971).

is 507 F.2d 206 (5th Cir. 1975), vacated, 507 F.2d 216 (5th Cir. 1975).

197 Id. at 213-14 (citing Bullock v. United States, 265 F.2d 683 (6th Cir.), cert. denied, 360 U.S. 909 (1959)); Kasper v. Brittain, 245 F.2d 92 (6th Cir.), cert. denied, 355 U.S. 834 (1957); Brewer v. Hoxie School Dist. No. 46, 238 F.2d 91 (8th Cir. 1956).

183507 F.2d at $213-14$

1" Id.

20 The court relied in large part on Cox, supra note 157, at 108-21. Professor Cox's article, however, concerned the power of Congress to enact antidiscrimination legislation under the enforcement clause of the fourteenth amendment, not whether the Ku Klux Klan Act did so. See also 52 B.U.L. Rev. 599, 617-18 (1972). 
and statutory grounds. Since United States $v$. Guest, ${ }^{201}$ it sometimes has been agued that Congress has the power, under the enforcement clause of the fourteenth amendment, to punish private interferences with the exercise of fourteenth amendment rights of others. ${ }^{202}$ To say that Congress has the power to create or enforce rights entirely between private persons, however, requires a significant leap beyond anything suggested in Guest. The congressional power to enforce the fourteenth amendment extends to the regulation of private activities that interfere with state provision of equal protection, or possibly with the exercise of rights that exist against the states. But no congressional action can elevate acts of private discrimination to the status of a constitutional deprivation.-

No constitutional analysis is required, however, to show that the Westberry court's conclusion was incorrect. Regardless of what powers Congress might exercise under modern theories of the enforcement clause, the Congress that enacted section 1985(c) operated under a more restrctive constitutional theory. As the legislative history shows, Congress did not believe that it had the power to reach private discriminatory conduct; it believed that its power extended only to securing state provision of equal protection against the depredations of private political conspirators. Without reaching the constitutional issue, it may be concluded that section 1985(c) does not reach mere "private aggression." 203

Most courts that have reached the question have rejected the Action-Westberry analysis, ${ }^{204}$ following instead then-Judge Stevens's opinion for the Seventh Circuit in Dombroswki v. Dowling. ${ }^{205}$

201383 U.S. 745 (1966). The defendants in Guest were indicted under 18 U.S.C. $\S 241$ in connection with the murder of a black man who sought to use publicly owned facilities in Athens, Georgia. The Court, in an opinion by Justice Stewart, sustained the indictment on the grounds that it could be construed to allege state involvement in the conspiracy. Two separate concurring opinions joined by six Justices, however, argued that Congress has the power under the enforcement clause of the fourteenth amendment to prevent private persons from interfering with the exercise of fourteenth amendment rights. The Guest theory accords with that held by the radicals in the 1871 Congress and opposed by the moderates who drafted the version of the bill that became section 1985(c). See Part II supra. Although the Griffin Court cited Guest for the proposition that the right to travel may be protected against private interference, 403 U.S. at 105-106, the Court specifically did not rely on the Guest interpretation of Congress's enforcement powers in locating the constitutional power to sustain section 1985(c) in the Griffin situation. Id. at 107.

${ }^{202}$ More often, the argument has been rejected, at least in its extreme form. See Note, supra note 114, at 511-17.

${ }^{203}$ See Cox, supra note 157, at 115.

20, See, e.g., Doski v. M. Goldseker Co., 539 F.2d 1326 (4th Cir. 1976); Reichardt v. Payne, 396 F. Supp. 1010, 1016-18 (N.D. Cal. 1975); Flores v. Yeska, 372 F. Supp. 35 (E.D. Wis. 1974); Note, supra note 114, at 516; Note, supra note 12.

${ }^{205} 459$ F.2d 190 (7th Cir. 1972). See also Cohen v. Ilinois Inst. of Technology, 524 F.2d 
The plaintiff, a criminal lawyer with a substantial black and latino clientele, was refused office space by a private real estate management firm. He sued under section 1985(c), alleging a conspiracy to deprive him of his right to be free of invidious discrimination in the rental of offices. The court rejected his argument: "Since the Fourteenth Amendment, unlike the Thirteenth, affords the plaintiff no protection against discrimination in which there is no state involvement of any kind, a private conspiracy which arbitrarily denies him access to private property does not abridge his Fourteenth Amendment rights." ${ }^{208}$ When the section 1985(c) plaintiff alleges deprivation of fourteenth amendment rights, the Dowling theory is consistent with the original meaning of the statute, since it confines the operation of the statute to enforcement of rights created against the state by that amendment.

The Dowling theory has, however, been misapplied by some courts to deny remedies to plaintiffs with causes of action under section 1985(c). For example, in Weiss v. Willow Tree Civic Association, ${ }^{207}$ Hasidic Jews who wanted to construct a housing development on their property alleged a conspiracy by defendants, all of whom were private persons or associations, to obstruct their application for a zoning permit. The plaintiffs claimed that the defendants sought to deprive them of their right to equal treatment by the zoning board, protected by the fourteenth amendment. The district court dismissed the suit, stating that where the right allegedly infringed arises under the fourteenth amendment, the section 1985 (c) cause of action entails a state action requirement. Since no state officials were involved in the conspiracy, the court held that the conspiracy was outside the coverage of section 1985(c). This position misconstrues the nature of state involvement necessary to state a section 1985(c) claim. As held in Dowling, the right infringed must be one that is protected against government infringement. When the government is forced or induced by private individuals to deny that right, no further official involvement in the conspiracy is required. ${ }^{208}$

A final area of confusion encompasses cases in which Congress's constitutional power to reach the conduct complained of clearly

818 (7th Cir. 1975) (Stevens, J.).

204459 F.2d at 196.

2047 U.S.L.W. 2513 (S.D.N.Y. Feb. 8, 1979).

208 The plaintiffs in Weiss need not necessarily prevail. To obtain damages, they must prove injury. See text at note 27 supra. Denial of a zoning permit may not constitute the injury to person, property, or legal rights that the statute requires. 
exists-for example, under the thirteenth amendment ${ }^{209}$ or under the power to protect the rights of national citizenship. ${ }^{210}$ Griffin was such a case. ${ }^{211}$ The existence of this power has led some courts to believe that all racially motivated conspiracies are proscribed by the Act; ${ }^{212}$ by analogy, all conspiracies to interfere with rights of national citizenship would also be proscribed. Griffin did not so hold. The Griffin Court first discussed whether the conduct complained of was comprehended by the statute; this discussion did not concern thirteenth amendment rights or rights of national citizenship. Only on the constitutional question were those rights considered important. ${ }^{213}$ But merely because the constitutional power exists, it should not be concluded that Congress in 1871 exercised that power to its fullest extent. At that time, Congressmen held more restricted constitutional theories than those prevalent today. Racially motivated conspiracies and conspiracies to infringe rights of national citizenship are not covered by section 1985 (c) unless they seek to obstruct governmental provision of equal protection.

Mark Fockele

${ }^{209}$ In Bethel v. Jendoco Constr. Corp., 570 F.2d 1168 (3d Cir. 1978), the court sustained a 1985(c) claim based on racially motivated employment discrimination by private construction companies and labor unions. The court said that the "complaint is replete with specific allegations of race-based discrimination-conduct proscribed by the Constitution and the remedy for which is provided by [section 1985(c)]." Id. at 1173. The court provided neither citation nor explanation for this remarkable assertion. Since the plaintiff's claims under section 1981 and Title VII were also sustained, it is difficult to see why the court desired to depart so sharply from the terms and purpose of section 1985(c).

210 See Means v. Wilson, 522 F.2d 833'(8th Cir. 1975), cert. denied, 424 U.S. 958 (1976) (statutory right to vote in Indian tribal elections). Rights of national citizenship are rights inherent in the relationship of citizen to the national government and may be protected by congressional action from private as well as public infringement. They include the right to vote, United States v. Classic, 313 U.S. 299 (1941); Ex parte Yarbrough, 110 U.S. 651 (1884), the right not to be attacked while in the custody of a federal marshall, Logan v. United States, 144 U.S. 263 (1892), the right to inform federal officials of violations of federal law, Motes v. United States, 178 U.S. 458 (1900); In re Quarles, 158 U.S. 532 (1895), and the right to travel between states, Shapiro v. Thompson, 394 U.S. 618 (1969).

211403 U.S. at 104-07.

${ }^{212}$ See The Supreme Court-1970 Term, supra note 142, at 99.

${ }_{213} 403$ U.S. at 105-06. "This and other evidence could make it clear that the petitioners had suffered from conduct that Congress may reach under its power to protect the right of interstate travel." Id. at 106 (emphasis added). 